IZA DP No. 6448

The Role of Salience in Performance Schemes:

Evidence from a Field Experiment

Florian Englmaier

Andreas Roider

Uwe Sunde

March 2012 


\title{
The Role of Salience in Performance Schemes: Evidence from a Field Experiment
}

\author{
Florian Englmaier \\ University of Würzburg
}

Andreas Roider

University of Heidelberg

and IZA

Uwe Sunde

University of St.Gallen

and IZA

\author{
Discussion Paper No. 6448 \\ March 2012
}

\author{
IZA \\ P.O. Box 7240 \\ 53072 Bonn \\ Germany \\ Phone: +49-228-3894-0 \\ Fax: +49-228-3894-180 \\ E-mail: iza@iza.org
}

\begin{abstract}
Any opinions expressed here are those of the author(s) and not those of IZA. Research published in this series may include views on policy, but the institute itself takes no institutional policy positions.

The Institute for the Study of Labor (IZA) in Bonn is a local and virtual international research center and a place of communication between science, politics and business. IZA is an independent nonprofit organization supported by Deutsche Post Foundation. The center is associated with the University of Bonn and offers a stimulating research environment through its international network, workshops and conferences, data service, project support, research visits and doctoral program. IZA engages in (i) original and internationally competitive research in all fields of labor economics, (ii) development of policy concepts, and (iii) dissemination of research results and concepts to the interested public.
\end{abstract}

IZA Discussion Papers often represent preliminary work and are circulated to encourage discussion. Citation of such a paper should account for its provisional character. A revised version may be available directly from the author. 


\section{ABSTRACT \\ The Role of Salience in Performance Schemes: Evidence from a Field Experiment ${ }^{*}$}

Incentive schemes affect performance and priorities of agents but, in reality, they can be complicated even for simple tasks. We analyze the effects of the salience of incentives in a team production setting where the principal has an interest in quantity and quality of output. We use data from a controlled field experiment that changed the communication of the incentive system without changing the incentive system. The results indicate that salience of incentives itself is statistically and economically important for performance. We find that higher salience of incentives for quantity increases quantity, reduces quality, and increases in-pocket income of team managers.

JEL Classification: M52, J30, D03, D80

Keywords: incentives, attention, salience, communication, field experiments

Corresponding author:

Uwe Sunde

University of St.Gallen

SEW-HSG

Varnbüelstrasse 14

$\mathrm{CH}-9000$ St.Gallen

Switzerland

E-mail: uwe.sunde@unisg.ch

\footnotetext{
* We thank participants at the Engelberg Seminar on Labor Economics, the Workshop on Natural Experiments and Controlled Field Studies in Holzhausen/Ammersee, the EALE-SOLE World Congress in London, the Econometric Society World Congress in Shanghai, and seminar audiences in Innsbruck, Toulouse, Chicago, Kellogg, IZA, and in particular Josh Angrist, Jordi Blanes-i-Vidal, Imran Rasul, Matthias Schündeln, Robert Ulbricht, and Fabian Waldinger for very helpful comments and suggestions. We thank the German Science Foundation (DFG) for financial support via SFB/TR-15. This paper also received funding from the European Commission's Seventh Research Framework Programme, under the project SCience, Innovation, FIrms and markets in a GLObalized World (SCIFIGLOW, Contract number SSH7-CT-2008-217436).
} 


\section{Introduction}

Incentive schemes, designed to enhance performance, are key elements in a firm's personnel policy and have been in the focus of empirical research in economics in recent years. At a general level, the main empirical findings could be summarized as "Incentives work, stronger incentives work better." [1 However, most of the evidence on causal effects comes from fairly simple incentive schemes and drastic interventions, as for example in Lazear's (2000) seminal Safelite study. In reality, however, many incentive schemes, and the organizational structures in which they are implemented, are complicated, even for simple tasks.

From a (standard) theoretical point of view, what matters for eliciting effort is to correctly design the material aspects of an incentive scheme. Whether agents in fact optimize against this scheme (in particular in situations where the scheme is complex) has, however, not received much attention. In this study, we are interested in the role of salience in complex incentive schemes. To address this question, we exploit data from a controlled field experiment in a large firm. The experiment varied how information about the performance scheme was communicated to team managers and team members, while keeping the explicit incentive structure unchanged. This randomized intervention allows us to identify the causal effects of changes in the salience of incentives on performance.

The experiment was conducted in cooperation with a large European agricultural producer. We have access to the complete personnel records for all field workers and teams for the entire 2008 harvest season (May-November). The workers' task is to harvest lettuce. Depending on the day, around 10 harvest teams work on different fields.2 Each team consists typically of more than 30 harvest workers that work on one harvesting machine and perform different tasks (cutters, packers, crate-staplers, stretchers, drivers). The respective team manager is the crucial link between management and field workers. Each team manager oversees the operations of a team and monitors the implementation of the harvest plan of the firm. In particular, the team manager is responsible for harvest performance and takes the relevant operative decisions (speed of harvesting machine, matching of team members to tasks, training of incoming team members) for the entire team. The team manager also communicates the details of the harvest plan, the output requirements, as well as

\footnotetext{
${ }^{1}$ For a survey, see e.g., Prendergast (1999).

${ }^{2}$ These fields are located in the region of the firm's headquarters, but teams in general work too far apart to be able to communicate.
} 
the incentive structure to the team members.

The firm cares about the harvested quantity and quality as it faces severe contractual penalties for inferior quality delivered to large supermarket chains. Accordingly, incentives are set twofold. Quantity incentives are provided via a piece rate. This rate is determined ex-ante by the firm's management for each team and shift separately in order to set incentives, but at the same time to adjust for varying conditions with respect to weather, field, crop, and demand. Quality incentives are provided via deductions from team pay for deficient quality as well as through a tournament scheme across teams in which the teams delivering the highest quality win monetary prizes. Quality is measured by regular (post-picking and pre-delivery) quality checks. The incentive structure is explained in more detail below.

We exploit a controlled experimental intervention, in which the salience of incentives was varied for a randomly selected subgroup of the harvest teams, while the actual monetary incentive system remained unchanged. In the experimental treatment, the firm changed the salience of ex-ante determined piece rates. The treatment period was the month of August 2008, and the treatment group consisted of five teams. Teams are identified by their managers. The remaining harvest teams (team managers) serve as control group. All team managers are experienced and have worked for the firm in this position already for several years prior to the experiment $!^{3}$ In the pre-intervention situation, team managers were informed about the pertaining piece rate when they reported to the firm's headquarters before the start of their respective shift. However, there was neither monitoring whether team managers acknowledged this crucial variable, nor whether they communicated it to their team members. The intervention ensured that team managers and team members received this information as the firm's mobile quality control team briefed team managers explicitly and posted a note visible to the entire team about the current piece rate on the harvest machine at the beginning of the shift. We interpret this intervention as increased salience of the quantity part of the incentive structure. However, given the experience of team managers (who, on average, have worked for the firm for several years) and given that incentive pay constitutes a substantial part of their income, standard theory would predict no effect of the intervention $4^{4}$

However, the findings suggest that increased salience of incentives causally

\footnotetext{
${ }^{3}$ There are no relevant career incentives in place as, historically, team managers have not been promoted to positions higher up in the firm's hierarchy.

${ }^{4}$ Team members' pay is entirely incentive-based, and the amount of money they earn while working for the firm constitutes a substantial fraction of their annual income.
} 
increases output by about 3.5-4\%, has a negative (but only marginally significant) effect on quality, and increases team managers' incomes by about 3.5-5\%. This effect is solely due to the fact that the details of the incentive scheme have been communicated more saliently to the team managers and their teams. Looking at the results in more detail, we find evidence that the treatment effect slowly built up, had a peak in the second half of August, and seems to have persisted beyond August 31. Moreover, improved salience led team managers to adjust their behavior more finely to material incentives (which vary across shifts and teams). Another piece of evidence for a change in team managers' behavior in response to increased salience is that the treatment seems to have induced team managers to change the assignment of tasks within teams, in terms of assigning more team members to work as cutters (the central and most demanding task in harvesting lettuce). Finally, our findings provide evidence for a persistent effect of salience on experienced team managers' behavior, even after the end of the treatment. The finding that variation in salience appears to have a more significant effect on quantity incentives than on quality incentives might be due to the fact that quality incentives are more complicated and have more indirect effects, as is explained in more detail below.

To summarize, our study documents that a change in salience of an incentive system that has been in place for several years and that remains unchanged (throughout the treatment and control periods and across treatment and control teams) has considerable effects on behavior in a real-world production environment with experienced agents and substantial monetary incentives.

With these results, our study contributes to a recent empirical literature that documents substantial effects of inattention and salience. Sofar, this literature has mostly focused on consumption choices and financial decision making. 5 For example, various authors consider online auctions, and show that bidders are inattentive to relevant information. In field experiments, Hossain and Morgan (2006) and Brown, Hossain, and Morgan (2010) document that, if the salience of shipping costs is low (for example, because they are stated separately from the price), shipping costs are not fully incorporated in buyers' bidding decisions. Lee and Malmendier (2011) show that bidders frequently fail to exercise available (advantageous) "buy-it-now" options. In a similar vein, the degree of salience of taxes seems to affect consumption behavior. For example, Chetty, Looney and Kroft (2009) conduct a field experiment at a grocery store and find that posting tax-inclusive prices reduces demand. Finkel-

\footnotetext{
${ }^{5}$ For a survey, see e.g., DellaVigna (2009). There is also a growing theoretical literature on inattention, see e.g., Grubb (2011) or Gabaix and Laibson (2006).
} 
stein (2009) shows that reduced salience of road tolls (caused by the introduction of electronic toll collection systems) leads to higher tolls ${ }^{6}$ In the realm of personal finance, Karlan, McConnel, Mullainathan and Zinman (2010) conduct a field experiment that documents that reminders that are sent to saving account holders are more effective in changing savings behavior when they increase the salience of a specific expenditure. In another field experiment, Stango and Zinman (2011) manipulate the salience of checking overdraft fees by injecting overdraft-related questions into surveys that consumers take. In their paper, increased salience has an immediate effect of reducing the likelihood of incuring a fee in the current month; in particular among consumers with relatively low education and financial literacy. Moreover, taking part in multiple overdraft-related surveys seem to build a "stock" of attention that reduces overdrafts for up to two years. Our paper adds to this literature by considering incentive provision in a firm and showing that salience substantially affects performance even in a context with experienced managers.

In the empirical literature on incentive provision in firms, there are some related papers that (while holding the incentive system fixed) vary the information that is provided to workers.7 For example, in a quasi-experiment, Blanes-i-Vidal and Nossol (2011) consider a setting where workers are paid piece rates and where management begins to reveal the relative position of workers in the pay and productivity distribution. It turns out that this additional information about relative performance leads to substantial and lasting increases in productivity (e.g., due to social comparison processes), though the material incentives have not changed 8 Similarly, Bandiera, Barankay, and Rasul (2011) show that introducing performance feedback, without changing incentives themselves, has measurable effects on output. In their study, feedback information generates incentives to change the (endogenous) team composition by making clear the benefits of assortative matching into teams by ability. In contrast, in our data the composition of teams in terms of the workforce is determined by the firm management and largely dependent on arrival and departure of seasonal workers at the firm site. Upon arrival workers are assigned to a team

\footnotetext{
${ }^{6}$ There is also evidence that consumers do not fully appreciate the continuity of price or quality measures, and instead frequently focus on a coarser grid of (focal) values when making decisions, see e.g., Lacetera, Pope, and Sydnor (2011) and Pope (2009).

${ }^{7}$ See Kluger and Denisi (1996) for a survey of the psychological literature on the effects of information interventions on performance.

${ }^{8}$ In a similar field-experiment, Barankay (2011) finds strong negative effects of rank information on performance among male employees.
} 
manager's team and stay there until the end of their stint at the farm. From the perspective of the analysis in this paper, team composition can therefore be seen as exogenous to the decisions of the team managers. Finally, Hossain and List (2012) report on a field experiment in a Chinese high-tech manufacturing facility where conditional incentives framed as either "losses" or "gains" were introduced. Both are shown to increase productivity, but performance persistently responds stronger to incentives that are framed as losses than to identical incentives that are framed as gains. Our paper differs from these studies (and hence contributes to this literature) because in our field experiment there was no additional information provided nor was the information framed differentially. Instead, team managers had, in principle, access to the same information in both control and treatment periods, and our intervention only increased the information's salience.

The remainder of the paper is structured as follows. Section 2 describes the data and the experimental intervention in more detail. Section 3 presents our results, and Section 4 discusses the results as well as potential interpretations.

\section{Experimental Design and Identification}

\subsection{Background Information}

Firm. The firm is a large European agricultural producer that mainly produces vegetables. For the current study, we use data on all teams that harvest (a certain variety of) lettuce, which is the firm's main product. The harvesting is done using a team technology, where on every day of the week around 10 teams independently from each other harvest lettuce in shifts on different fields in the same geographical region. Each team typically consists of more than 30 harvest workers. These workers are mostly seasonal workers from Eastern Europe (mainly from Poland, Romania, or Ukraine). Teams are organized according to different tasks (manager, cutters, packers, crate-staplers, stretchers, drivers).$^{9}$ The teams work on separate plots, and

\footnotetext{
${ }^{9}$ Unlike team managers, drivers, stretchers, and administrative staff (who are typically permanent employees), harvest workers (like cutters or packers) only stay with the firms for less than a harvest season, typically 6-8 weeks. Typically, they are bused to the firm's premises from their country of origin. There, they live in dorms and are allocated to teams. Workers are typically recruited in their home towns, often upon recommendation by workers from previous years. Arrival and departure are organized by the firm in batches of bus loads to make travel time and cost-efficient. Although there are considerable differences in the production technology (and the
} 
each team works on a harvest machine that economizes the entire harvest process. The team manager represents the most important team member and identifies a team in our data. He is the link between management and workers, communicates details about the incentive structure, and takes all relevant decisions on the field, like the speed of the harvesting machine, the assignment of team members to tasks, training of incoming team members, and the like. The team manager is ultimately responsible for the entire harvest performance of his team, in terms of quantity and quality of the harvested lettuce. The decision about how fast the harvest is conducted (and hence, indirectly, how much lettuce is worth harvesting on a given field) is taken by the team manager. The data contains the complete personnel records for all field workers and teams for the harvest season 2008, which lasted from May 25 to November 6, 2008.

Firm's Objectives. The firm cares about quantity and quality of the harvested lettuce. A higher quantity obviously increases revenue, but due to severe contractual penalties for inferior quality delivered to large supermarket chains, low quality is very costly to the firm. As a consequence, the management sets twofold incentives. Incentives for quantity are set through piece rates for the amount of lettuce harvested. Piece rates are determined ex ante each day before a shift begins. Incentives for quality are set through deductions from pay in terms of "quality (malus) points". These are determined by regular quality checks, post-picking and pre-delivery, where malus points are given for deficient quality in certain dimensions. The quality checks are conducted by quality control staff of the firm, and quality points are assigned to the entire team. Moreover, based on the quality point scores (where a higher score reflects worse quality), there is a daily tournament among the harvest teams.

Firm's Policies: Quantity Incentives. The central incentive device for quantity is the piece rate per lettuce head. The piece rate is set daily for each team and shift by the harvest manager (a member of the firm's central management) in order to incentivize the team 10 Importantly, additional adjustments are made to the piece rate to account for varying harvesting conditions, such as the conditions

respective product), the composition of the workforce is comparable to the one in the recent studies by Bandiera et al. (2007, 2009, 2010, 2011).

${ }^{10}$ In particular, the firm fixes a "gross per crate price" as well as a target crate size in terms of the number of lettuce heads per crate before the shift begins. The effective "piece rate" is then given by the "gross per crate price" divided by the target number of pieces (6-8 depending on crop conditions) per crate. 
of the field (e.g., soil or field size), crop (e.g., size of the lettuce heads, maturity, or potential damages), as well as general harvesting conditions (e.g., weather or temperature) 11 These additional adjustments to the piece rate are made because the firm aims to ensure that workers obtain an average hourly wage above the legal minimum. For a given team and shift, the average hourly pay of a team member from quantity incentives is given by the piece rate times the total number of pieces harvested divided by the total number of work hours. According to the company's internal guide book for team managers "it is the responsibility of the team manager to inform all team members about the piece rate before the shift begins".

Firm's Policies: Quality Incentives. Quality is ensured by regular quality checks (post-picking and pre-delivery). Deficient quality reduces a team member's pay directly through deductions, which are proportional to the assigned number of quality (malus) points (in particular, the respective deduction is given by the number of quality points times total pieces harvested). These deductions (i.e., the fines for bad quality) are payed into a pool. At the end of the harvest day, this pool is distributed among those teams with the highest quality (lowest number of malus points) of all teams on that day according to the outcome of a "quality tournament" between all teams. The teams with the best quality performance (the lowest number of quality malus points) receive the prizes (which are allocated according to a fixed-percentage distribution scheme that is known to all team managers and team members) with the best performing team collecting the largest share of the pool. The absolute size of the prizes in this tournament is determined endogenously by the size of the pool on the respective harvest day, i.e., by the quality performance of all teams harvesting on that day.

Firm's Policies: Team Manager's Incentives. The firm explicitly specifies targets for the team manager. These targets include low costs for harvesting by efficient instruction and task assignment in his team, high quality of the harvest, high yield from a given harvest plot, good maintenance of machines, and economical

\footnotetext{
${ }^{11}$ Relating the piece rate to the amount of rainfall (in liters per square meter) and to the daily maximum temperature (in degrees centigrade) that was forecasted for the respective harvest day in the harvesting area on the day before, the data show a positive correlation between the forecasted precipitation and the piece rate (pairwise correlation $0.14, \mathrm{p}$-value $<0.01$ ) and a negative correlation between the forecasted maximum temperature and the piece rate (pairwise correlation before September 1 is -0.18 , p-value $<0.01$, and -0.07 , p-value $<0.02$ over the entire season). However, note that the effect of current weather on both current and future harvesting conditions is fairly complicated, and hence only certain combinations of weather conditions will affect harvesting conditions negatively.
} 
usage of material. To achieve these goals, the firm uses a compensation scheme for team managers that consists of several components. A team manager receives a base wage according to the pay scale for a gardener's assistant that results from collective bargaining agreements, plus a bonus as performance compensation from which a fix amount is deducted for each of the quality malus points assigned to his team in the respective shift. These deductions are pooled and distributed as prizes in a daily quality tournament among all team managers that has the same structure as the quality tournament described above. In addition, as in the case of the team members, the team manager receives a performance pay component that varies in the piece rate and in the quantity harvested. Generally speaking, however, quality incentives are relatively strong for team managers compared to team members. Finally, the team manager participates in the profits of the firm's profit center "harvest". In particular, a certain percentage of the profits generated on a harvest day is distributed among all team managers that were active on that day, in proportion to their harvest performance.

\subsection{Experimental Treatment}

The experimental treatment was conducted in the treatment period August 1 August 31, 2008. The treated population consisted of 5 randomly selected team managers and their teams, while the control population consisted of the remaining team managers and their harvest teams. The control period was May 25 - July 31 and September 1 - November 6, 2008. The experimental intervention changed the salience of quantity incentives, while keeping the actual monetary incentive system fixed. Before the intervention, team managers were informed about their respective piece rate when they reported to the firm's headquarters before the start of their shift. However, there was no monitoring as to whether team managers actually acknowledge this information or whether they communicate the piece rate to their team members. The intervention made sure that team managers and team members receive and acknowledge this relevant information. The intervention was conducted by the mobile quality control team. The mobile quality control team (responsible for checking the production process on site at the different harvest machines) visits each team at the beginning of its shift (both in the treatment and control periods). Hence, the quality team's visit is not per se perceived as an unexpected intervention. In the treatment period, before the shift began, the quality control team briefed (treated) team managers explicitly about the pertaining piece rate and posted a note stating 
the piece rate on the harvest machine where it was visible to all team members. Beyond this (and its usual quality control tasks), the quality control team did not intervene in the production process.

\subsection{Data}

Our unit of observation are data on the team-shift level for the entire harvest season from May 25 to November 6, 2008 (yielding 1,199 team-shift observations).12 All variables (except binary indicator variables and fractions) have been standardized to a mean of zero and a standard deviation of one to protect sensitive information of the firm.

In the raw data, there is no evidence for systematic differences in observable characteristics between treatment and control teams. The workforce of the treated teams is slightly younger and has slightly lower tenure (in terms of seasons it has worked for the firm). These differences are, however, minor and do not vary systematically across control and treatment periods. Treated teams exhibit a slightly shorter harvest experience in the current season. This difference might be driven by differences in the timing of arrival and departure of seasonal workers that are randomly distributed to the different teams. However, this difference is unlikely to affect performance given the simplicity of the tasks and the required (short) training period ${ }^{13}$ There are no significant differences in inputs (in terms of number of workers per shift and total worker hours per shift) between treatment and control teams, neither during treatment nor control periods. Most importantly, incentives in terms of the piece rate set by the firm do not differ systematically between teams receiving the treatment and teams that are in the control group, neither before nor

\footnotetext{
${ }^{12}$ Less than $5 \%$ of shifts are shifts of a team that has already completed an earlier shift on a different field on the same day (where such second shifts tend to be short). The analysis below is based on a sample that drops these 53 (second) observations of a given team on a given day, and controls for this fact with a dummy indicating whether the team worked an additional second shift on the respective day. This implies that we base our analysis on variation on the team-day level. Including the second shifts in the estimation sample (or, alternatively, dropping all teams with multiple shifts on a given day) delivers virtually identical results (which are available upon request).

${ }^{13}$ Upon arrival, new workers typically work on a fixed daily wage for 1 to 2 days while practicing their task, and switch to incentive pay thereafter. In the analysis, we only consider teams that work on performance pay, eliminating approximately $15 \%$ of team-shift observations, in which teams are working on fixed wages due to bad conditions or other reasons unrelated to the intervention.
} 
during the treatment 14

At a later stage in the harvest season, there was a policy change as the firm adjusted the way in which the quality tournament outcomes were communicated. This policy change started on September 1, 2008 (i.e., after the end of the experimental intervention), and was in place until the end of the harvest season. In particular, before September 1, the quality scores of individual teams (and their team managers) were communicated to each team separately once a week, and no ranking or information on relative outcomes was provided by the firm's management. After September 1, quality scores of all teams plus the ranking of all teams was communicated to all teams every workday. We control for this change in policy in our analysis by allowing for day fixed effects.

\subsection{Identification}

The purpose of our study is to test the hypothesis that a change in the salience of incentives (i.e., in the way piece rates were communicated to team managers and members) has no effect on performance as the actual incentives remain unchanged. By design, treatment effects of the experimental intervention can be identified by ways of a difference-in-difference analysis. The unit of observation is a shift (teamday) observation, where teams are identified through the respective team manager. The empirical model is

$$
Y_{i t}=\beta \mathcal{I}_{\text {Treated Team }} \cdot \mathcal{I}_{\text {Treatment Day }}+\alpha X_{i t}+\gamma_{i} \mathcal{I}_{i}+\delta_{t} \mathcal{I}_{t}+\varepsilon_{i t}
$$

where $i$ and $t$ denote team and day, respectively, $Y$ is the respective outcome of interest, $X$ are controls on the team-day basis, $\mathcal{I}_{i}$ and $\mathcal{I}_{t}$ represent binary team and day indicators, and $\gamma$ and $\delta$ are the respective coefficients of team (manager) and harvest day fixed effects. The coefficient of interest is $\beta$, which reflects the effect of the treatment period on treated teams. In other words, regression (1) represents a difference-in-difference estimation, where treated teams are compared to control groups that did not receive the salience treatment.

The fact that the treatment constitutes a change in the informational environment poses a slight difficulty in defining treatment and control periods. While the time before the treatment, i.e., before August 1, serves as control, it is not entirely clear how to deal with the period after the end of the treatment. Strictly speaking,

\footnotetext{
${ }^{14}$ The respective p-values from t-tests are 0.33 over the entire season, and 0.19 and 0.86 before and during the treatment period, respectively.
} 
the experimental treatment was only applied between August 1 and 31, implying that the period after August 31 should be viewed as control period. However, it might as well be that once the importance and functioning of incentives became more salient to treated team managers, they changed their behavior even without the quality control team explicitly pointing out daily incentives as during the intervention period. In this case, the entire period after August 1 would constitute a treatment period ${ }^{15}$ In the following, we present results for both identification assumptions, i.e., a treatment period from August 1-31, or from August 1-November 6, 2008. In all cases, the coefficient of interest, $\beta$, measures the effect of the treatment on treated teams compared to the respective outcomes in control teams, i.e., the treatment effect on the treated.

As discussed above, the firm changed some details in the way quality tournaments were conducted after the treatment period ended. To account for this policy change, which affected all teams alike, harvest day fixed effects are included in the estimation equation.

We estimate different versions of model (1). In particular, we present different estimates using OLS with robust standard errors that account for possible correlations in the error structure. In one specification, we allow for errors to be correlated within a team (team manager) across harvest days, which accounts for systematic unobserved heterogeneity in leadership skills or style across team managers. Alternatively, we allow for clustering on harvest day across teams, reflecting correlations in the errors on the same day for instance due to weather effects or due to the daily quality tournaments. As a third possibility, we allow for clustering along both dimensions, reflecting the possibility that there is a correlation in errors for team manager across days, as well as a correlation within a day across teams. Finally, we present GLS estimates that allow for team-specific serial correlation in the disturbances and heteroscedasticity across teams.

All specifications include controls for factors that might determine performance but that can be plausibly viewed as given from the perspective of the team manager. In particular, this includes the material incentives in terms of the piece rate set by the firm in advance of the respective shift. The controls also include information regarding team composition in terms of the average age of team members, the av-

\footnotetext{
${ }^{15}$ Note that communication between team managers about incentives, or the intervention itself, cannot be ruled out. Increased salience of incentives for non-treated team managers through such communication should bias any treatment effect toward zero, however. This implies that the results presented below should be seen as conservative estimates of the true effect.
} 
erage tenure of team members (in terms of seasons they have worked for the firm), as well as the average duration of employment in harvest of team members in the current season (in days) in order to account for potential productivity differences across teams. These team characteristics are computed for team members excluding the team manager and change over the harvesting season within teams as there is continuous arrival and departure of seasonal workers in a particular team manager's team. In addition, the specifications include controls for team size and total work hours to account for variations in terms of the labor force at the disposal of a team manager in a given shift, because it is the firm, and not the team manager, that decides on these variables ${ }^{16}$ As discussed earlier, we also include a binary indicator that takes value 1 if a team continued to work on a second shift on a given day.

\section{Results}

Quantity. To examine potential effects of a change in the salience of incentives, we begin by estimating the effect of the experimental treatment on the daily performance of teams in terms of the total amount of lettuce harvested per shift and team. We estimate several specifications that make different assumptions about the determinants of the team production process and that use different estimation methods. In particular, we allow for different error structures, with standard errors being clustered on the team level, on the day level, two-way clustering on team and day level, and for autoregressive disturbances.

The results are displayed in Table 1. Column (1) presents results from a standard difference-in-difference setting. The treatment effect is estimated as the coefficient on a binary indicator that takes value 1 for treated teams during the treatment period, and zero otherwise. Indicator variables for treated teams and the treatment period are absorbed by team and day indicators. Since team performance is likely to vary systematically across teams, standard errors in this specification are corrected for clustering on the team level.

The results indicate a positive treatment effect in the sense that the explicit announcement of incentives in fact increased performance in the quantity domain.

\footnotetext{
${ }^{16}$ In unreported regressions we have checked whether the treatment had any impact on the length of shifts or breaks (in hours). This would indicate that beyond the firm's directives, team managers have some leeway with respect to total work hours (e.g., in order to increase output if this seems profitable). However, this does not seem to be the case. Details are available upon request.
} 
The effect is 0.134 standard deviations and marginally significant, with a p-value of 0.06 based on team-cluster robust standard errors. Quantitatively, this increase corresponds to a 3.5-4\% increase in the quantity of lettuce harvested per shift.

In terms of other determinants of harvest performance, the results show that the piece rate has a negative effect on the quantities harvested. This reflects the fact that, as discussed earlier, when setting the piece rate, the firm's management also accounts for more difficult harvesting conditions across harvesting plots ${ }^{17}$ Among the team composition variables, mean years of experience of the team members (i.e., tenure) has a significantly positive effect on quantity performance, while days worked in harvest in the current season has no effect. Team size appears to have a significant positive effect, as do total work hours per shift. Larger teams that work longer hours harvest significantly more lettuce. Notably, this simple specification explains already almost 90 percent of the total variation in harvested quantity.

Since some harvest conditions (such as weather) are arguably correlated across teams on a given day, error terms across teams on a given harvest day may show a systematic correlation as well. Column (2) therefore presents the results for the same specification (with team and day fixed effects), but with robust standard errors that allow for clustering within day, rather than team. Due to the fact that the analysis is based on a narrow long panel with up to 13 cross-sectional units (teams) and up to 165 time periods (harvest days), clustering on the team level implies slightly different standard errors than clustering at the day level. As consequence, while all coefficient estimates, in particular the treatment effect, are the same as in specification (1), standard errors and hence statistical significance differ. When considering the treatment effect of the experimental intervention, however, the effect is still positive and now even significant at the $3 \%$ level . All other results are very similar, as well.

Since there are reasonable arguments for systematic correlations in the unobserved heterogeneity for a given team over time, as well as for a given day across all teams, Column (3) presents a third specification that allows for two-way clustering of the standard errors, following the approach by Cameron, Gelbach and Miller (2011). Again, this leaves the point estimates unchanged but affects standard errors by making them robust to arbitrary correlation across time for teams, and for arbitrary correlation across teams for a given day. Given the panel structure, two-way

\footnotetext{
${ }^{17}$ While weather conditions are likely to be taken up by day fixed effects, there remain team-shift specific harvesting conditions, such as size and condition of the respective field or size, maturity, and condition of the crop on the respective field.
} 
clustering increases the standard errors, but the treatment effect is still marginally significant with a p-value of .07. In light of the fact that the specification contains both team and day fixed effects, clustering standard errors on team and day might be considered overly conservative, however 18

Finally, column (4) presents results from GLS estimates that allow for AR(1) disturbances that might differ across teams, as well as for heteroscedasticity across teams. The results from this estimation method are quantitatively very similar to those in columns (1)-(3). In particular, the point estimates of the effects are very similar. The treatment effect on quantity is 0.138 and thus even slightly larger (and significant at the $5 \%$ level).

Columns (5)-(8) contain results for specifications that treat the entire harvest period after August 1 as treatment period, i.e., including the period after September 1 when the actual intervention had already been terminated. This specification is motivated by the observation that the intervention aimed at changing the team managers' awareness of the compensation system and the relevant elements of that system, such as the respective piece rate for the given shift. This awareness can be hypothesized to remain higher even after the end of the actual treatment period. The results from this specification are qualitatively and quantitatively similar. The treatment effect is slightly smaller and statistically significant at 5\% in the specification with the alternative definition of the treatment period, regardless of the assumed error structure and estimation method. Also the results for the other variables are almost identical, suggesting that the re-definition of the treatment period does not greatly affect the overall picture.

Motivated by the findings of Table 1, it seems interesting to look more closely at the dynamic structure of the treatment effect. To which degree did treated teams change their behavior immediately after the treatment commenced, and to which degree did the treatment effect persist even after the quality teams had stopped ensuring that treated teams were informed about the piece rate? In order to obtain a better understanding of the time structure of the effects, Table 2 presents estimation results for specifications in which the treatment period August is split up into two sub-periods, covering the first and the second half of August, respectively. In analogy to Table 1. columns (1)-(4) contain the respective results when considering only August as treatment period, while columns (5)-(8) contain results when adding a

\footnotetext{
${ }^{18}$ As noted by Thompson (2010), two-way clustered standard errors have less bias, but exhibit more variance. Moreover, given the panel structure with large $T$ (days) and small $N$ (teams), clustering on teams already accounts for most of the systematic correlation in the error structure.
} 
separate treatment effect for the period after August 31.

Table 2 reveals that there is a positive treatment effect, regardless of how the treatment periods is defined, but its size and significance varies. Consistently, the treatment effect for the first half of August is small and insignificant. However, regardless of the assumed error structure, the treatment had a significant effect in the second half of August, which is about twice as large as the average effect over the entire treatment period in August in Table 1. This effect is significant in all specifications, and even slightly stronger results are obtained when also accounting for an additional treatment dummy in the after-August period, as reported in columns (5)-(8). Columns (5)-(8) also reveals a sizable treatment effect for the period after August 31, which is, however, only marginally significant with p-values between .06 and .09. Taken together these results show that the treatment effect needed time to build up with a peak in the second half of August, and there is some evidence that it persisted well beyond the end of the actual treatment period 19 The estimates of the coefficients of all control variables are virtually identical to those obtained from the baseline specification in Table 1 .

The above results provide a first indication that the null (i.e., that a change in the way incentives were communicated had no effect on performance as the actual incentives remained unchanged) can be rejected. Harvesting performance in terms of quantity changed in response to making the relevant incentives more salient to team managers and team members.

Quality. To investigate this finding further, we repeat the same analysis (using the same specifications as in Tables 11 for performance in terms of quality instead of quantity as outcome. The dependent variable is quality (malus) points, where a higher value corresponds to lower quality. Table 3 presents the respective results for the baseline specification. Overall, the performance of the empirical model is weaker for quality than for quantity, as suggested by the comparably low $R$-squared and the fact that beyond team and day dummies none of the controls appears to have a significant effect on quality. In terms of treatment effect over the period August 1-31, we find a positive but only marginally significant or insignificant effect in the specifications (1)-(4), with p-values between .08 and .23 depending on the

\footnotetext{
${ }^{19}$ These dynamics speak against our treatment effect being caused by a Hawthorne Effect, i.e., an immediate increase in performance simply due to the fact that there was some intervention (which then may decrease over time). See Levitt and List (2011) for a (critical) discussion of the Hawthorne Effect.
} 
assumptions about the error structure. These results might be the consequence of substantial randomness in the determination of quality points (because of random sampling on part of the quality control staff of the firm) as well as due to the fact that quality is measured on a rather course grid of quality malus points. Nonetheless, when interpreting the treatment effect qualitatively, there is a weak indication that more salient quantity incentives might have lead to higher priority for quantity at the cost of quality (i.e., leading to a higher number of quality malus points). In terms of economic significance of the effect, treatment makes quality points go up for the treated group by more than 5 percent. Both economically and statistically, the effects are weaker when applying the alternative treatment period definition, using the entire period after August 1 as treatment period. The respective results results are shown in columns (5)-(8) of Table 3. Additional unreported results provide no evidence for a significant treatment effect on quality when distinguishing treatment effects over different sub-periods of the treatment 20

Since the team faces a multi-tasking problem - harvesting a large quantity at a high quality - estimating quantity and quality jointly might be more efficient. Table 4 therefore presents the results from SUR estimations of quantity and quality outcomes for the specifications with August as treatment period (columns (1) and (2)), as well as for the entire harvest season after August 1 as treatment period (columns (3) and (4)). The specifications include quality (quantity) in the quantity (quality) regressions as additional controls. The results are unaffected by this and quantitatively and qualitatively almost identical when eliminating these controls. The estimates deliver practically identical coefficients as in the baseline specifications in Tables 1 and 3 , but the results are statistically more significant as would be expected if estimation is more efficient ${ }^{21}$ Nevertheless, the effect of the treatment on quality performance remains relatively weak.

Compensation. An important question concerning the treatment effect is whether the salience of incentives had an effect on the earnings of the team managers, in particular in light of the fact that the main decisions about the relevant harvest parameters, such as speed of the harvesting machine, or the attention devoted to quantity and quality, are made by the team manager. The results for the team manager's total daily earnings are presented in Table 5. The estimates are obtained

\footnotetext{
${ }^{20}$ Detailed results are available upon request.

${ }^{21}$ However, the standard errors do not account for clustering, and hence should be seen as a lower bound.
} 
with the baseline specifications, but with the manager's total daily compensation as dependent variable. As discussed in Section 2, this compensation includes a fix wage component, components for quantity and quality harvested, and earnings from participation in the profits of the profit center "harvest" at the firm level. Columns (1)-(4) contain results for August as treatment period. The treatment effect is positive and significant at least at the $6 \%$ level in this specification, indicating that the team managers were able to achieve higher daily compensation in response to the experimental variation in the salience of incentives. Quantitatively, the effect corresponds to a pay rise of 3.5-5 percent compared to the average compensation per day. Moreover, team managers earn more if there is a higher number of total work hours per shift and less if they had to do another shift afterwards. ${ }^{22}$ The results are similar, but show a somewhat smaller and statistically weaker treatment effect when considering the period after August 1 as treatment.

Table 6 presents the results for a more detailed analysis of the timing of the effect by splitting the treatment period into sub-periods. The results indicate again that the effect of the treatment on the team managers' compensation mainly materialized in the second half of August, consistent with the earlier findings that the quantity effects of the treatment were largest in the second half of August.

Robustness. The results are confirmed by several robustness checks. We obtain qualitatively similar results when using non-standardized variables, or nonstandardized controls with logged outcome variables 23 With these specifications, the results are qualitatively identical and even quantitatively very close to the results obtained with standardized variables. For instance, with respect to quantity, using non-standardized variables yields a treatment effect of about 5\%, while using a logged quantity performance measure yields a treatment effect of $5.2 \%$, which compares closely to the quantity effect of $3.5-4 \%$ derived in Table 1. Similar comments apply to the results for quality and team managers' earnings.

\footnotetext{
${ }^{22}$ Daily earnings are computed here as the daily earnings from the respective shift under consideration, but do not incorporate earnings from a potential second shift.

${ }^{23}$ Detailed results are available upon request.
} 


\section{Discussion}

This paper provides evidence that a change in the salience of incentives had effects on performance and earnings in a real production setting, even though the material incentive system remained unchanged. Studying a high stakes work environment with experienced team managers and unchanged material incentives, we find relatively strong effects of a comparatively mild, purely informational intervention. This section offers a discussion of potential reasons for this finding.

The intervention provided only information on the piece rate to the treated team managers that they already had prior to the intervention. However, by repeating the same information, the intervention might have increased the team managers' awareness of the particular incentives on a given day. Hence, explanations based on fully rational decision makers that costlessly process information appear inconsistent with the above findings, whereas a salience based explanation might be more promising. The strong positive treatment effect on the team managers' earnings suggests that this change in awareness led the team managers to modify their behavior in order to maximize their payoffs. In the pre-intervention situation, the team manager might not have paid sufficient attention to the variations in the piece rate, and the information contained in its day-to-day adjustments. This might be due to routine or due to an unjustified focus on quality. Arguably, such a focus might be expected to be induced by the competitive character of awarding prizes and by the relatively large prize sums that are awarded. In other words, pre-intervention the quality component of the incentive scheme might have been more salient by construction, and the intervention could have mitigated this.

Additional evidence corroborates such an interpretation. First, if team managers of treated teams changed their behavior in response to the treatment, their performance should reflect variations in actual incentives more closely than as it does for non-treated teams. Hence, one might expect that, as a result of the treatment, output correlates more strongly with the piece rate, i.e., team managers adjust behavior more finely to the changed material incentives and the information contained in the piece rate. Table 7 presents results that test this hypothesis by estimating the baseline specification of Table 1. In addition, this specification includes an interaction term between the treatment indicator (a binary indicator that takes value 1 for treated team managers during the respective treatment period) and the piece rate. The results indeed deliver a significant interaction between material incentives (piece rate) and the treatment effect. This finding is consistent with the hypothesis 
that once the incentives are more salient, treated team managers focus more on quantity if quantity incentives are high.

Second, one would expect that it takes a while before treated team managers are able to change their output in response to more salient incentives (e.g., because it takes time to recalibrate the relative importance given to quantity and quality of harvest output). The evidence presented in Table 2 is consistent with the hypothesis of a learning period and a successive increase in the effect during the treatment period. However, one might also hypothesize that an increased salience makes team managers realize instantaneously that the piece rate contains relevant information that they have not appropriately acknowledged before, and to react accordingly. This would then suggest that the performance of treated team managers should react instantaneously to variations in incentives relative to non-treated team managers. To test this hypothesis, we replicate the analysis of Table 7, but also allow for the interaction effect to vary during the treatment period. The results are shown in Table 8. Consistent with the hypothesis, we find evidence for a significant interaction between the treatment and the piece rate from the beginning of the treatment period in early August onwards. The size of the coefficient on the interaction term is even larger in the second half of August, and it remains positive and significant even after the treatment ended on August 31. At the same time, the pattern of main effects of the treatment is the same, with the treatment effect being insignificant in the first half of August, as in Tables 2 and 7 . Together, the results in Table 8 therefore support the hypothesis that team managers who received a treatment in terms of increased salience of incentives changed their behavior instantaneously, but that it took some time for these changes to show an overall effect.

Third, Tables 1 and 7 reveal that there remains a significant (non-interacted) treatment effect (i.e., during the treatment period treated teams harvest a higher quantity per se). This suggests other policy changes by the team manager, such as a different allocation of tasks within teams. The central task in the harvesting is the cutting of lettuce on the ground. Assigning a larger share of workers to be cutters might increase harvest output in terms of quantity, but might lead to a more superficial packing and processing of the harvested crop, and hence reduce quality. To test this hypothesis, we estimate a model with the fraction of the team working as cutters as dependent variable, using the same specification as in the baseline analysis for quantity and quality. The results are depicted in Table 9. The coefficient estimates suggest that none of the controls affects the team composition systematically 
except team size ${ }^{24}$ In terms of a treatment effect, the results indeed provide an indication that team managers use task allocation as a means to manipulate team performance (i.e., they seem to assign more workers to be cutters). However, the effect is quantitatively fairly small and not always statistically significant.

An alternative, distinct channel through which the treatment might affect harvest performance is by ensuring that the team members have access to the information about the relevant quantity incentives. While it is difficult to disentangle this effect from the effects due to changes in the team manager's supervision behavior, one implication of an effect working through team members as channel is that the treatment effect should disappear with the departure of the team members that experienced the treatment period with increased salience of incentives. In other words, once a majority of seasonal workers that experienced the treatment has left after the end of the treatment, the treatment effect should abate. In contrast, if the treatment effect persisted, this would be indirect evidence for salience working mainly through changes in the team managers' behavior. In the data, we indeed see a sharp drop in the tenure of team members of treated harvest teams in the first half of September.25 Nevertheless, the estimation results shown in Tables 7 and 8 reveal a persistence of the effect of increased salience even in the entire period after August 31:26 Unreported results from more flexible specifications that allow for different treatment effects and interactions with piece rates for the first half of September, the second half of September, and the period in October reveal a significant interaction between treatment effect and piece rates throughout, and a significant main effect of the treatment also after the first half of September ${ }^{27}$ These findings corroborate the hypothesis of increased salience of incentives mainly affecting outcomes because of changes in the team managers' behavior, rather than changes in the behavior of team members only. Additional unreported results also show no effect of the treatment on the daily compensation of team members 28

\footnotetext{
${ }^{24}$ In larger teams, a larger share of workers is assigned to cutting lettuce, which might be expected given that the harvest machines have a limited number of workplaces for other tasks (such as packing, stapling, foiling-in and transporting the baskets), whereas the space for cutters is such that the number of cutters can be adjusted relatively more easily if the team size varies.

${ }^{25}$ This is illustrated by a sharp drop in the duration of cutters in the teams of the treated team managers during early September, which is not visible in the control teams.

${ }^{26}$ The persistence of the effects of increased salience corroborates similar findings of persistence in the context of household finance by Stango and Zinman (2011).

${ }^{27}$ The detailed results are available upon request.

${ }^{28}$ Regression results for the average hourly wage of team members as dependent variable show
} 
Summing up, incentive schemes and hierarchies are complicated in reality, even for simple tasks. As many studies have shown, incentive schemes affect performance and priorities of agents. Our study indicates that salience of an incentive system is important for performance even in an environment with experienced agents. Using data from a controlled field experiment, our results document that a change in communication of incentives, while holding the actual incentive structure fixed, has quantitatively and qualitatively relevant effects on performance. We find that ensuring more transparency of the entire performance pay system increases output (quantity), tends to reduce quality, and increases the team managers' incomes.

An important open question that cannot be addressed in the present context due to the lack of data access is the effect of the change in the salience of the incentive scheme on costs and profits of the firm. More work is needed to obtain a better understanding of the effects of complex organizations, such as team production structures with intricate multi-level performance schemes, on performance and profits.

that the experimental intervention had no effect, regardless of the specification of the control period, suggesting that incentive salience did not play a role for the wages of team members. Similar results are found when using the daily earnings of cutters only as dependent variable. 


\section{References}

Bandiera, O., I. Barankay, and I. Rasul (2007) "Incentives for Managers and Inequality among Workers: Evidence from a Firm-Level Experiment," Quarterly Journal of Economics, Vol. 122, pp. 729-773.

Bandiera, O., I. Barankay, and I. Rasul (2009) "Social Connections and Incentives in the Workplace: Evidence from Personnel Data," Econometrica, Vol. 77, pp. 1047-1094.

Bandiera, O., I. Barankay, and I. Rasul (2010) "Social Incentives in the Workplace," Review of Economic Studies, Vol. 77, pp. 417-459.

Bandiera, O., I. Barankay, and I. Rasul (2011) "Team Incentives: Evidence from a FirmLevel Experiment," Journal of the European Economic Association, forthcoming.

Barankay, I. (2011) "Rank Incentives: Evidence from a Field Experiment," mimeo, Wharton School of Business, University of Pennsylvania.

Blanes-i-Vidal, J., and M. Nossol (2011) "Tournaments without Prizes: Evidence from Personnel Records," Management Science, Vol. 57, pp. 1721-1736.

Brown, J., T. Hossain, and J. Morgan (2010) "Shrouded Attributes and Information Suppression: Evidence from the Field," Quarterly Journal of Economics, Vol. 125, pp. 859876.

Cameron, C., J. Gelbach, and D. Miller (2011) "Robust Inference with Multi-Way Clustering," Journal of Business and Economic Statistics, Vol. 29, pp. 238-249.

Chetty, R., A. Looney, and K. Kroft (2009) "Salience and Taxation: Theory and Evidence," American Economic Review, Vol. 99, pp. 1145-1177.

DellaVigna, S. (2009) "Psychology and Economics: Evidence from the Field," Journal of Economic Literature, Vol. 47, pp. 315-372.

Finkelstein, A. (2009) "EZ-Tax: Tax Salience and Tax Rates," Quarterly Journal of Economics, Vol. 124, pp. 969-1010.

Gabaix, X. and D. Laibson (2006) "Shrouded Attributes, Consumer Myopia, and Information Suppression in Competitive Markets," Quarterly Journal of Economics, Vol. 121, pp. 505-540.

Grubb, M. (2011) "Bill Shock: Inattention and Price-Posting Regulation," Working Paper.

Hossain, T. and J.A. List (2012) "The Behavioralist Visits the Factory: Increasing Productivity Using Simple Framing Manipulations," Management Science, forthcoming. 
Hossain, T. and J. Morgan (2006) “...Plus Shipping and Handling: Revenue (Non) Equivalence in Field Experiments on eBay," B.E. Journals in Economic Analysis and Policy: Advances in Economic Analysis and Policy, Vol. 6, pp. 1-27.

Karlan, D., M. McConnel, S. Mullainathan, and J. Zinman (2010) "Getting to the Top of Mind: How Reminders Increase Saving," NBER Working Paper 16205.

Kluger, A. and Denisi, A. (1996) "The Effects of Information Interventions on Performance: A Historical Review, a Meta-Analysis and a Preliminary Information Intervention Theory", Psychological Bulletin, Vol. 119, pp. 254-284.

Lacetera, N., D. Pope, and J. Sydnor (2011) "Heuristic Thinking and Limited Attention in the Car Market," American Economic Review, forthcoming.

Lazear, E.P. (2000) "Performance Pay and Productivity," American Economic Review, Vol. 90, pp. 1346-61.

Lee, Y.H. and U. Malmendier (2011) "The Bidder's Curse," American Economic Review, Vol. 101, pp. 749-787.

Levitt, S. and J. List (2011) "Was There Really a Hawthorne Effect at the Hawthorne Plant? An Analysis of the Original Illumination Experiments," American Economic Journal: Applied Economics, Vol. 3, pp. 224-238.

Pope, D. (2009) "Reacting to Rankings: Evidence from 'America's Best Hospitals'," Journal of Health Economics, Vol. 28, pp. 1154-1165.

Prendergast, C. (1999) "The Provision of Incentives in Firms," Journal of Economic Literature, Vol. 37, pp. 7-63.

Stango, V. and J. Zinman (2011) "Limited and Varying Consumer Attention: Evidence from Shocks to the Salience of Bank Overdraft Fees," NBER Working Paper 17028.

Thompson, S.B. (2011) "Simple Formulas for Standard Errors that Cluster by Both Firm and Time," Journal of Financial Economics Vol. 99, pp. 1-10. 
Table 1: Results: Quantity

\begin{tabular}{|c|c|c|c|c|c|c|c|c|}
\hline & \multicolumn{8}{|c|}{ Pieces Harvested } \\
\hline & \multicolumn{4}{|c|}{ Treatment: August 1-31 } & \multicolumn{4}{|c|}{ Treatment: after August 1} \\
\hline & $(1)$ & $(2)$ & $(3)$ & $(4)$ & $(5)$ & $(6)$ & $(7)$ & $(8)$ \\
\hline $\begin{array}{l}\text { Treatment Effect } \\
\text { [s.e.] } \\
\text { (p-value) }\end{array}$ & $\begin{array}{l}0.134^{*} \\
{[0.061]} \\
(0.051)\end{array}$ & $\begin{array}{c}0.134^{* *} \\
{[0.060]} \\
(0.029)\end{array}$ & $\begin{array}{l}0.134^{*} \\
{[0.074]} \\
(0.070)\end{array}$ & $\begin{array}{c}0.138^{* *} \\
{[0.060]} \\
(0.023)\end{array}$ & $\begin{array}{c}0.121^{* *} \\
{[0.041]} \\
(0.013)\end{array}$ & $\begin{array}{c}0.121 * * \\
{[0.050]} \\
(0.016)\end{array}$ & $\begin{array}{c}0.121 * * \\
{[0.052]} \\
(0.019)\end{array}$ & $\begin{array}{c}0.122^{* *} \\
{[0.050]} \\
(0.015)\end{array}$ \\
\hline Piece Rate & $\begin{array}{c}-0.213 * * * \\
{[0.047]}\end{array}$ & $\begin{array}{c}-0.213^{* * *} \\
{[0.049]}\end{array}$ & $\begin{array}{c}-0.213 * * * \\
{[0.056]}\end{array}$ & $\begin{array}{c}-0.209 * * * \\
{[0.014]}\end{array}$ & $\begin{array}{c}-0.212^{* * *} \\
{[0.048]}\end{array}$ & $\begin{array}{c}-0.212^{* * *} \\
{[0.049]}\end{array}$ & $\begin{array}{l}-0.212^{* * *} \\
{[0.057]}\end{array}$ & $\begin{array}{c}-0.208 * * * \\
{[0.014]}\end{array}$ \\
\hline $\begin{array}{l}\text { Mean Age } \\
\text { (All Team Members) }\end{array}$ & $\begin{array}{l}-0.019 \\
{[0.032]}\end{array}$ & $\begin{array}{l}-0.019 \\
{[0.022]}\end{array}$ & $\begin{array}{l}-0.019 \\
{[0.034]}\end{array}$ & $\begin{array}{l}-0.017 \\
{[0.025]}\end{array}$ & $\begin{array}{l}-0.025 \\
{[0.030]}\end{array}$ & $\begin{array}{l}-0.025 \\
{[0.022]}\end{array}$ & $\begin{array}{l}-0.025 \\
{[0.033]}\end{array}$ & $\begin{array}{l}-0.023 \\
{[0.025]}\end{array}$ \\
\hline $\begin{array}{l}\text { Mean Years of Experience } \\
\text { (All Team Members) }\end{array}$ & $0.168^{* * *} *$ & $\begin{array}{l}0.168^{* * *} * \\
{[0.027]}\end{array}$ & $0.168^{* * *}$ & $\begin{array}{c}0.166^{* * * *} \\
{[0.026]}\end{array}$ & $0.168^{* * *}$ & $\begin{array}{c}0.168^{* * *} * \\
{[0.027]}\end{array}$ & $0.168^{* * *} *$ & $\begin{array}{c}0.168^{* * *} \\
{[0.025]}\end{array}$ \\
\hline $\begin{array}{l}\text { Mean Days Worked in the Current } \\
\text { Season (All Team Members) }\end{array}$ & $\begin{array}{c}0.04 \\
{[0.058]}\end{array}$ & $\begin{array}{c}0.04 \\
{[0.050]}\end{array}$ & $\begin{array}{c}0.04 \\
{[0.066]}\end{array}$ & $\begin{array}{c}0.026 \\
{[0.044]}\end{array}$ & $\begin{array}{l}0.065 \\
{[0.053]}\end{array}$ & $\begin{array}{c}0.065 \\
{[0.051]}\end{array}$ & $\begin{array}{l}0.065 \\
{[0.063]}\end{array}$ & $\begin{array}{c}0.042 \\
{[0.045]}\end{array}$ \\
\hline Team Size & $\begin{array}{c}0.110 * * * \\
{[0.013]}\end{array}$ & $\begin{array}{l}0.110^{* * *} \\
{[0.015]}\end{array}$ & $\begin{array}{l}0.110^{* * * *} \\
{[0.018]}\end{array}$ & $\begin{array}{c}0.113^{* * * *} \\
{[0.012]}\end{array}$ & $\begin{array}{c}0.112^{* * * *} \\
{[0.013]}\end{array}$ & $\begin{array}{c}0.112^{* * *} * \\
{[0.015]}\end{array}$ & $\begin{array}{c}0.112^{* * * *} \\
{[0.019]}\end{array}$ & $\begin{array}{c}0.114^{* * *} * \\
{[0.012]}\end{array}$ \\
\hline Total Work Hours per Shift & $\begin{array}{c}0.907 * * * \\
{[0.020]}\end{array}$ & $\begin{array}{l}0.907^{* * *} \\
{[0.019]}\end{array}$ & $\begin{array}{c}0.907 * * * \\
{[0.028]}\end{array}$ & $\begin{array}{c}0.911 * * * \\
{[0.012]}\end{array}$ & $\begin{array}{c}0.907 * * * \\
{[0.020]}\end{array}$ & $\begin{array}{c}0.907 * * * \\
{[0.019]}\end{array}$ & $\begin{array}{c}0.907 * * * \\
{[0.028]}\end{array}$ & $\begin{array}{c}0.910 * * * \\
{[0.012]}\end{array}$ \\
\hline First of Two Shifts & $\begin{array}{l}-0.024 \\
{[0.030]}\end{array}$ & $\begin{array}{l}-0.024 \\
{[0.046]}\end{array}$ & $\begin{array}{l}-0.024 \\
{[0.045]}\end{array}$ & $\begin{array}{l}-0.038 \\
{[0.036]}\end{array}$ & $\begin{array}{l}-0.024 \\
{[0.032]}\end{array}$ & $\begin{array}{l}-0.024 \\
{[0.046]}\end{array}$ & $\begin{array}{l}-0.024 \\
{[0.045]}\end{array}$ & $\begin{array}{l}-0.038 \\
{[0.036]}\end{array}$ \\
\hline Observations & 1,199 & 1,199 & 1,199 & 1,199 & 1,199 & 1,199 & 1,199 & 1,199 \\
\hline R-squared & 0.894 & 0.894 & 0.894 & & 0.894 & 0.894 & 0.894 & \\
\hline
\end{tabular}

Note: Observations are on the team-shift level. The dependent variable is total pieces of lettuce harvested. All variables except binary treatment indicators are standardized on the estimation sample. Columns (1),(2), (3), and (5), (6) and (7) show OLS estimates. Robust standard errors are shown in square brackets. Standard errors are clustered on the team level (col. (1) and (5)) or the day level (col. (2), (6)), or on team and day (col. (3), (7)), respectively. Columns (4) and (8) show GLS estimates, accounting for team-specific AR(1) disturbances within teams and heteroscedasticity across teams. $* * *, * *, *$ indicate significance at $1-, 5-$, and 10 -percent level, respectively.

Table 2: Results: Quantity over Time

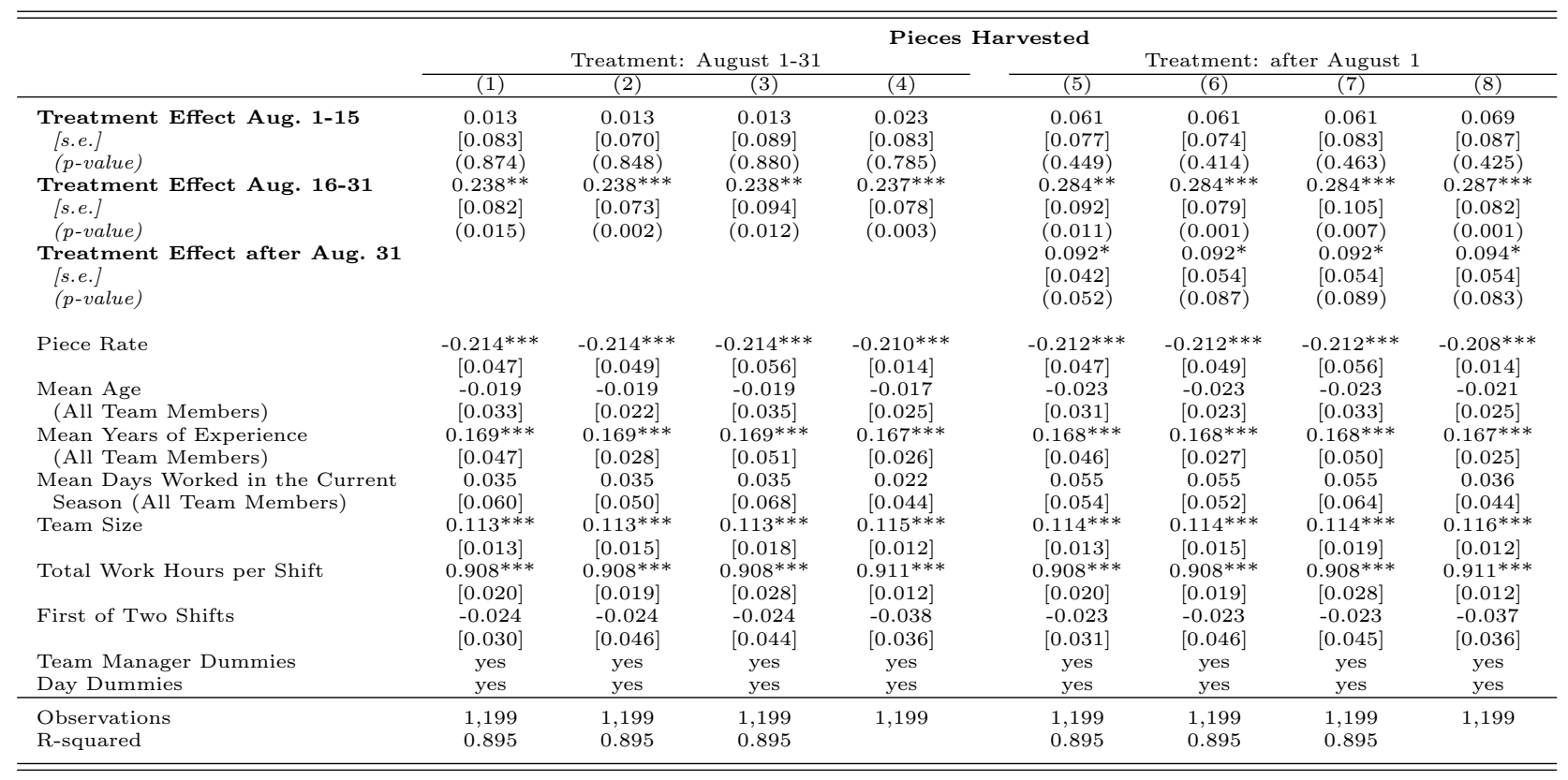

Note: Observations are on the team-shift level. The dependent variable is total pieces of lettuce harvested. All variables except binary treatment indicators are standardized on the estimation sample. Columns (1),(2), (3), and (5), (6) and (7) show OLS estimates. Robust standard errors are shown in square brackets. Standard errors are clustered on the team level (col. (1) and (5)) or the day level (col. (2), (6)), or on team and day (col. (3), (7)), respectively. Columns (4) and (8) show GLS estimates, accounting for team-specific AR(1) disturbances within teams and heteroscedasticity across teams. $* * *, * *, *$ indicate significance at $1-, 5-$, and 10 -percent level, respectively. 
Table 3: Results: Quality

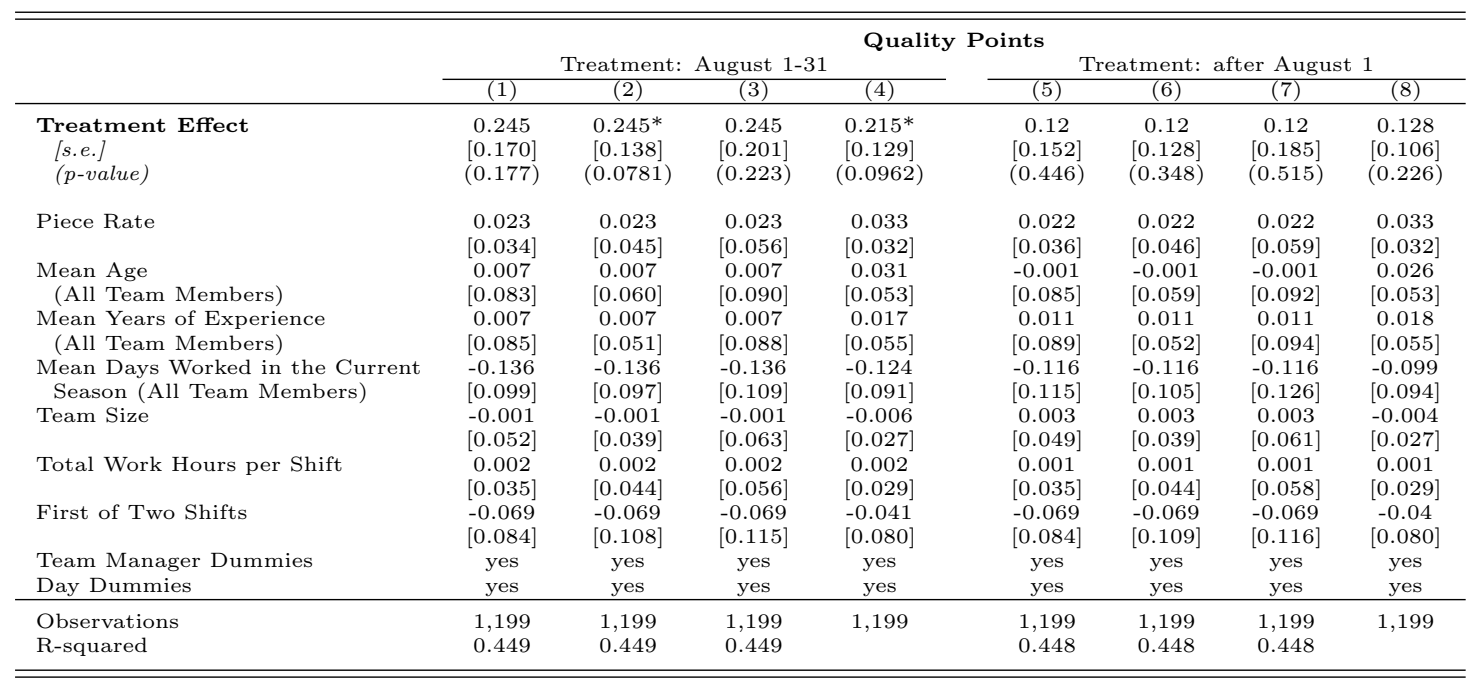

Note: Observations are on the team-shift level. The dependent variable is the number of quality (malus) points. All variables except binary treatment indicators are standardized on the estimation sample. Columns (1),(2), (3), and (5), (6) and (7) show OLS estimates. Robust standard errors are shown in square brackets. Standard errors are clustered on the team level (col. (1) and (5)) or the day level (col. (2), (6)), or on team and day (col. (3), (7)), respectively. Columns (4) and (8) show GLS estimates, accounting for team-specific AR(1) disturbances within teams and heteroscedasticity across teams. ***, **,* indicate significance at 1-, 5-, and 10 -percent level, respectively.

Table 4: Results: Quantity and Quality (Joint Estimation)

\begin{tabular}{|c|c|c|c|c|}
\hline \multirow{2}{*}{$\begin{array}{l}\text { Treatment Period } \\
\text { Dependent Variable }\end{array}$} & \multicolumn{2}{|c|}{ August 1-31 } & \multicolumn{2}{|c|}{ After August 1} \\
\hline & $\frac{\text { Quantity }}{(1)}$ & $\frac{\text { Quality Points }}{(2)}$ & $\frac{\text { Quantity }}{(3)}$ & $\frac{\text { Quality Points }}{(4)}$ \\
\hline $\begin{array}{l}\text { Treatment Effect } \\
\text { [s.e.] } \\
\text { (p-value) }\end{array}$ & $\begin{array}{l}0.132 * * * \\
{[0.051]} \\
(0.010)\end{array}$ & $\begin{array}{c}0.240^{* *} \\
{[0.116]} \\
(0.038)\end{array}$ & $\begin{array}{c}0.120^{* * *} \\
{[0.042]} \\
(0.004)\end{array}$ & $\begin{array}{l}0.115 \\
{[0.096]} \\
(0.231)\end{array}$ \\
\hline Piece Rate & $\begin{array}{c}-0.214^{* * *} \\
{[0.015]}\end{array}$ & $\begin{array}{c}0.031 \\
{[0.037]}\end{array}$ & $\begin{array}{l}-0.212^{* * *} \\
{[0.015]}\end{array}$ & $\begin{array}{c}0.032 \\
{[0.037]}\end{array}$ \\
\hline $\begin{array}{l}\text { Mean Age } \\
\text { (All Team Members) }\end{array}$ & -0.019 & $\begin{array}{l}0.008 \\
{[0.051]}\end{array}$ & -0.025 & -0.001 \\
\hline $\begin{array}{l}\text { Mean Years of Experience } \\
\text { (All Team Members) }\end{array}$ & $\begin{array}{c}0.168^{* * *} * \\
{[0.022]}\end{array}$ & $\begin{array}{c}0.001] \\
0.001 \\
{[0.052]}\end{array}$ & $\begin{array}{c}0.168^{* * *} \\
{[0.022]}\end{array}$ & $\begin{array}{c}{[0.051]} \\
0.003 \\
{[0.052]}\end{array}$ \\
\hline $\begin{array}{l}\text { Mean Days Worked in the Current } \\
\text { Season (All Team Members) }\end{array}$ & $\begin{array}{c}0.041 \\
{[0.039]}\end{array}$ & $\begin{array}{l}-0.138 \\
{[0.089]}\end{array}$ & $\begin{array}{c}0.066 \\
{[0.040]}\end{array}$ & $\begin{array}{l}-0.119 \\
{[0.092]}\end{array}$ \\
\hline Team Size & $\begin{array}{c}0.110^{* * * *} \\
{[0.012]}\end{array}$ & $\begin{array}{l}-0.005 \\
{[0.027]}\end{array}$ & $\begin{array}{c}0.112^{* * *} \\
{[0.012]}\end{array}$ & $\begin{array}{l}-0.002 \\
{[0.028]}\end{array}$ \\
\hline Total Work Hours per Shift & $\begin{array}{c}0.907^{* * *} * \\
{[0.013]}\end{array}$ & $\begin{array}{l}-0.034 \\
{[0.067]}\end{array}$ & $\begin{array}{c}0.907^{* * *} * \\
{[0.013]}\end{array}$ & $\begin{array}{l}-0.042 \\
{[0.067]}\end{array}$ \\
\hline Second of Two Shifts & $\begin{array}{l}-0.024 \\
{[0.036]}\end{array}$ & $\begin{array}{l}-0.068 \\
{[0.082]}\end{array}$ & $\begin{array}{l}-0.023 \\
{[0.036]}\end{array}$ & $\begin{array}{l}-0.068 \\
{[0.082]}\end{array}$ \\
\hline Quality Points & $\begin{array}{c}0.008 \\
{[0.013]}\end{array}$ & & $\begin{array}{c}0.009 \\
{[0.013]}\end{array}$ & \\
\hline Quantity & & $\begin{array}{c}0.04 \\
{[0.066]}\end{array}$ & & $\begin{array}{c}0.047 \\
{[0.066]}\end{array}$ \\
\hline $\begin{array}{l}\text { Team Manager Dummies } \\
\text { Day Dummies }\end{array}$ & $\begin{array}{l}\text { yes } \\
\text { yes }\end{array}$ & $\begin{array}{l}\text { yes } \\
\text { yes }\end{array}$ & $\begin{array}{l}\text { yes } \\
\text { yes }\end{array}$ & $\begin{array}{l}\text { yes } \\
\text { yes }\end{array}$ \\
\hline Observations & 1,199 & 1,199 & 1,199 & 1,199 \\
\hline
\end{tabular}

Note: Observations are on the team-shift level. The dependent variables are total pieces of lettuce harvested and number of quality (malus) points, respectively. All variables except binary treatment indicators are standardized on the estimation sample. Columns (1)-(2) show SUR estimates for a treatment period defined as August 1-31. Columns (3)-(4) show SUR estimates for a treatment period defined as the harvest period after August 1. Standard errors are shown in square brackets. $* * *, * *, *$ indicate significance at $1-, 5-$, and 10 -percent level, respectively. 
Table 5: Results: Team Manager's Total Daily Earnings

\begin{tabular}{|c|c|c|c|c|c|c|c|c|}
\hline & \multicolumn{8}{|c|}{$\begin{array}{l}\text { Total Daily Earnings of Team Manager } \\
\text { Treatment: August } 1-31\end{array}$} \\
\hline & $(1)$ & $(2)$ & $(3)$ & $(4)$ & $(5)$ & $(6)$ & $(7)$ & $(8)$ \\
\hline $\begin{array}{l}\text { Treatment Effect on Treated } \\
\text { [s.e.] } \\
\text { (p-value) }\end{array}$ & $\begin{array}{l}0.173^{*} \\
{[0.082]} \\
(0.0589)\end{array}$ & $\begin{array}{c}0.173^{* * *} \\
{[0.055]} \\
(0.00211)\end{array}$ & $\begin{array}{l}0.173^{*} \\
{[0.089]} \\
(0.0520)\end{array}$ & $\begin{array}{l}0.195^{* *} \\
{[0.080]} \\
(0.0149)\end{array}$ & $\begin{array}{c}0.138 \\
{[0.110]} \\
(0.238)\end{array}$ & $\begin{array}{l}0.138^{* *} \\
{[0.062]} \\
(0.0286)\end{array}$ & $\begin{array}{l}0.138 \\
{[0.118]} \\
(0.244)\end{array}$ & $\begin{array}{l}0.150^{* *} \\
{[0.067]} \\
(0.0241)\end{array}$ \\
\hline Piece Rate & $\begin{array}{l}-0.019 \\
{[0.024]}\end{array}$ & $\begin{array}{l}-0.019 \\
{[0.025]}\end{array}$ & $\begin{array}{l}-0.019 \\
{[0.031]}\end{array}$ & $\begin{array}{l}-0.016 \\
{[0.019]}\end{array}$ & $\begin{array}{l}-0.017 \\
{[0.024]}\end{array}$ & $\begin{array}{l}-0.017 \\
{[0.026]}\end{array}$ & $\begin{array}{l}-0.017 \\
{[0.031]}\end{array}$ & $\begin{array}{l}-0.015 \\
{[0.019]}\end{array}$ \\
\hline $\begin{array}{l}\text { Mean Age } \\
\text { (All Team Members) }\end{array}$ & $\begin{array}{c}0.008 \\
{[0.047]}\end{array}$ & $\begin{array}{c}0.008 \\
{[0.030]}\end{array}$ & $\begin{array}{c}0.001] \\
0.008 \\
{[0.052]}\end{array}$ & -0.017 & $\begin{array}{c}0.001 \\
{[0.048]}\end{array}$ & $\begin{array}{c}0.001 \\
{[0.031]}\end{array}$ & {$[0.001$} & $\begin{array}{l}-0.025 \\
{[0.033]}\end{array}$ \\
\hline $\begin{array}{l}\text { Mean Years of Experience } \\
\text { (All Team Members) }\end{array}$ & $\begin{array}{c}0.097 \\
{[0.067]}\end{array}$ & $\begin{array}{l}0.097^{* *} \\
{[0.039]}\end{array}$ & $\begin{array}{c}0.097 \\
{[0.071]}\end{array}$ & $\begin{array}{l}0.081 * * \\
{[0.034]}\end{array}$ & $\begin{array}{c}0.098 \\
{[0.065]}\end{array}$ & $\begin{array}{l}0.098^{* *} \\
{[0.038]}\end{array}$ & $\begin{array}{c}0.098 \\
{[0.070]}\end{array}$ & $\begin{array}{l}0.081 * * \\
{[0.034]}\end{array}$ \\
\hline $\begin{array}{l}\text { Mean Days Worked in the Current } \\
\text { Season (All Team Members) }\end{array}$ & $\begin{array}{l}-0.039 \\
{[0.059]}\end{array}$ & $\begin{array}{l}-0.039 \\
{[0.061]}\end{array}$ & $\begin{array}{l}-0.039 \\
{[0.068]}\end{array}$ & $\begin{array}{l}-0.045 \\
{[0.056]}\end{array}$ & $\begin{array}{l}-0.012 \\
{[0.069]}\end{array}$ & $\begin{array}{l}-0.012 \\
{[0.062]}\end{array}$ & $\begin{array}{l}-0.012 \\
{[0.078]}\end{array}$ & $\begin{array}{c}-0.02 \\
{[0.058]}\end{array}$ \\
\hline Team Size & $\begin{array}{l}-0.013 \\
{[0.022]}\end{array}$ & $\begin{array}{l}-0.013 \\
{[0.021]}\end{array}$ & $\begin{array}{l}-0.013 \\
{[0.029]}\end{array}$ & $\begin{array}{l}-0.012 \\
{[0.016]}\end{array}$ & $\begin{array}{c}-0.01 \\
{[0.022]}\end{array}$ & $\begin{array}{c}-0.01 \\
{[0.020]}\end{array}$ & $\begin{array}{c}-0.01 \\
{[0.029]}\end{array}$ & $\begin{array}{l}-0.011 \\
{[0.016]}\end{array}$ \\
\hline Total Work Hours per Shift & $\begin{array}{c}0.812^{* * *} \\
{[0.033]}\end{array}$ & $\begin{array}{l}0.812^{* * *} \\
{[0.027]}\end{array}$ & $\begin{array}{l}0.812^{* * *} \\
{[0.044]}\end{array}$ & $\begin{array}{l}0.827^{* * *} * \\
{[0.017]}\end{array}$ & $\begin{array}{l}0.811^{* * *} \\
{[0.034]}\end{array}$ & $\begin{array}{l}0.811^{*} * * \\
{[0.027]}\end{array}$ & $\begin{array}{c}0.811^{* * *} * \\
{[0.045]}\end{array}$ & $\begin{array}{c}0.827 * * * \\
{[0.017]}\end{array}$ \\
\hline First of Two Shifts & $\begin{array}{c}-0.541 * * * \\
{[0.092]}\end{array}$ & $\begin{array}{c}-0.541^{* * *} \\
{[0.105]}\end{array}$ & $\begin{array}{c}-0.541^{* * *} \\
{[0.137]}\end{array}$ & $\begin{array}{c}-0.400 * * * \\
{[0.048]}\end{array}$ & $\begin{array}{c}-0.540 * * * \\
{[0.095]}\end{array}$ & $\begin{array}{c}-0.540 * * * \\
{[0.105]}\end{array}$ & $\begin{array}{c}-0.540^{* * *} \\
{[0.139]}\end{array}$ & $\begin{array}{c}-0.396 * * * \\
{[0.048]}\end{array}$ \\
\hline Day Dummies & yes & yes & yes & yes & yes & yes & yes & yes \\
\hline Observations & 1,199 & 1,199 & 1,199 & 1,199 & 1,199 & 1,199 & 1,199 & 1,199 \\
\hline R-squared & 0.807 & 0.807 & 0.807 & & 0.807 & 0.807 & 0.807 & \\
\hline
\end{tabular}

Note: Observations are on the team-shift level. The dependent variable are the total daily earnings of the team manager. All variables except binary treatment indicators are standardized on the estimation sample. Columns (1)-(2) and (4)-(5) show OLS estimates. Robust standard errors are shown in square brackets. Standard errors are clustered on the team level (col. (1), (4)) or the day level (col. (2), (5)), respectively. Columns (3) and (6) show GLS estimates, accounting for team-specific AR(1) disturbances within teams and heteroscedasticity across teams. Dependent variable is total daily earnings of the team manager. $* * *, * *, *$ indicate significance at $1-, 5-$, and $10-$ percent level, respectively.

Table 6: Results: Team Manager's Total Daily Earnings over Time

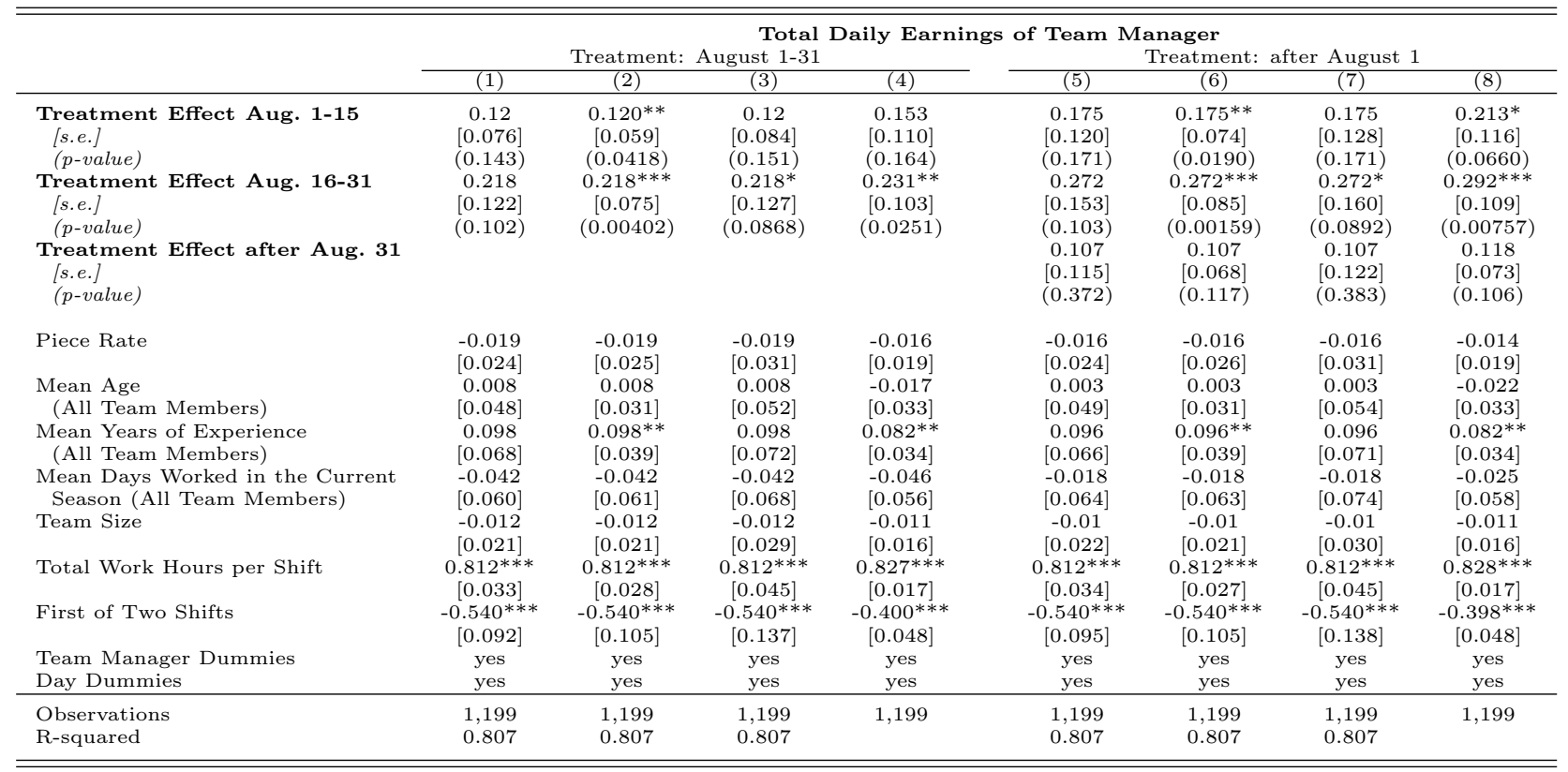

Note: Observations are on the team-shift level. The dependent variable are the total daily earnings of the team manager. All variables except binary treatment indicators are standardized on the estimation sample. Columns (1),(2), (3), and (5), (6) and (7) show OLS estimates. Robust standard errors are shown in square brackets. Standard errors are clustered on the team level (col. (1) and (5)) or the day level (col. (2), (6)), or on team and day (col. (3), (7)), respectively. Columns (4) and (8) show GLS estimates, accounting for team-specific AR(1) disturbances within teams and heteroscedasticity across teams. $* * *, * *, *$ indicate significance at $1-, 5-$, and 10 -percent level, respectively. 
Table 7: Results: Interactions between Treatment and Piece Rates

\begin{tabular}{|c|c|c|c|c|c|c|c|c|}
\hline & \multicolumn{8}{|c|}{ Pieces Harvested } \\
\hline & \multirow{2}{*}{\multicolumn{2}{|c|}{$\frac{\text { Treatment: }}{(2)}$}} & \multirow{2}{*}{$\begin{array}{c}\text { August } 1-31 \\
(3)\end{array}$} & \multirow{2}{*}{ (4) } & \multicolumn{4}{|c|}{ Treatment: after August 1} \\
\hline & & & & & $(5)$ & $(6)$ & $(7)$ & $(8)$ \\
\hline $\begin{array}{l}\text { Treatment Effect } \\
\text { [s.e.] }\end{array}$ & $\begin{array}{l}0.136^{*} \\
{[0.068]}\end{array}$ & $\begin{array}{c}0.136 * * \\
{[0.059]}\end{array}$ & $\begin{array}{l}0.136^{*} \\
{[0.079]}\end{array}$ & $\begin{array}{c}0.139^{* *} \\
{[0.061]}\end{array}$ & $\begin{array}{c}0.162^{* * * *} \\
{[0.042]}\end{array}$ & $\begin{array}{c}0.162^{* * * *} \\
{[0.049]}\end{array}$ & $\begin{array}{c}0.162 * * * \\
{[0.052]}\end{array}$ & $\begin{array}{c}0.163 * * * \\
{[0.050]}\end{array}$ \\
\hline Interaction: & $0.146^{* * *}$ & $0.146^{* * *}$ & $0.146^{* * *}$ & $0.163^{* * *}$ & $0.143^{* * *}$ & $0.143^{* * *}$ & $0.143^{* * *}$ & $0.153^{* * *}$ \\
\hline Treatment Effect . Piece Rate & [0.041] & [0.043] & {$[0.050]$} & [0.038] & [0.042] & [0.025] & {$[0.045]$} & [0.023] \\
\hline Piece Rate & $\begin{array}{c}-0.212^{* * *} * \\
{[0.046]}\end{array}$ & $\begin{array}{c}-0.212^{* * *} \\
{[0.049]}\end{array}$ & $\begin{array}{c}-0.212^{* * *} * \\
{[0.055]}\end{array}$ & $\begin{array}{c}-0.208 * * * \\
{[0.014]}\end{array}$ & $\begin{array}{c}-0.208 * * * \\
{[0.047]}\end{array}$ & $\begin{array}{c}-0.208 * * * \\
{[0.048]}\end{array}$ & $\begin{array}{c}-0.208 * * * \\
{[0.056]}\end{array}$ & $\begin{array}{c}-0.204^{* *} \\
{[0.014]}\end{array}$ \\
\hline $\begin{array}{l}\text { (All Team Members) } \\
\text { Mean Years of Experience }\end{array}$ & {$[0.032]$} & {$[0.022]$} & {$[0.034]$} & {$[0.025]$} & {$[0.030]$} & {$[0.022]$} & {$[0.033]$} & {$[0.025]$} \\
\hline $\begin{array}{l}\text { Mean Years of Experience } \\
\text { (All Team Members) }\end{array}$ & $\begin{array}{c}0.168^{* * *} \\
{[0.045]}\end{array}$ & $\begin{array}{c}0.168^{* * *} \\
{[0.027]}\end{array}$ & $\begin{array}{c}0.168^{* * *} \\
{[0.048]}\end{array}$ & $\begin{array}{c}0.170^{* * *} \\
{[0.026]}\end{array}$ & $\begin{array}{c}0.160^{* * *} * \\
{[0.045]}\end{array}$ & $\begin{array}{c}0.160^{* * *} * \\
{[0.027]}\end{array}$ & $\begin{array}{c}0.160 * * * \\
{[0.049]}\end{array}$ & $\begin{array}{c}0.160 * * * \\
{[0.025]}\end{array}$ \\
\hline Mean Days Worked in the Current & 0.034 & 0.034 & 0.034 & 0.018 & 0.054 & 0.054 & 0.054 & 0.034 \\
\hline Season (All Team Members) & {$[0.055]$} & {$[0.049]$} & {$[0.063]$} & {$[0.044]$} & [0.049] & {$[0.051]$} & {$[0.060]$} & {$[0.044]$} \\
\hline Team Size & $\begin{array}{l}0.109^{* * *} \\
{[0.012]}\end{array}$ & $\begin{array}{c}0.109^{* * *} \\
{[0.015]}\end{array}$ & $\begin{array}{l}0.109^{* * *} \\
{[0.018]}\end{array}$ & $\begin{array}{c}0.113^{* * *} \\
{[0.011]}\end{array}$ & $\begin{array}{c}0.108^{* * *} \\
{[0.012]}\end{array}$ & $0.108^{* * *}$ & $\begin{array}{c}0.108^{* * *} \\
{[0.018]}\end{array}$ & $\begin{array}{c}0.111^{* * *} \\
{[0.011]}\end{array}$ \\
\hline Total Work Hours per Shift & $0.895^{* * *}$ & $0.895^{* * *}$ & $0.895^{* * *}$ & $0.895^{* * *}$ & $0.874^{* * *}$ & $0.874^{* * *}$ & $0.874^{* * *}$ & $0.869^{* * *}$ \\
\hline & {$[0.025]$} & {$[0.020]$} & {$[0.031]$} & [0.013] & {$[0.036]$} & {$[0.021]$} & {$[0.041]$} & [0.013] \\
\hline First of Two Shifts & -0.028 & -0.028 & -0.028 & -0.043 & -0.022 & -0.022 & -0.022 & -0.039 \\
\hline Day Dummies & yes & yes & yes & yes & yes & yes & yes & yes \\
\hline Observations & 1,199 & 1,199 & 1,199 & 1,199 & 1,199 & 1,199 & 1,199 & 1,199 \\
\hline $\mathrm{R}$-squared & 0.895 & 0.895 & 0.895 & & 0.897 & 0.897 & 0.897 & \\
\hline
\end{tabular}

Note: Observations are on the team-shift level. The dependent variable is total pieces of lettuce harvested. All variables except binary treatment indicators are standardized on the estimation sample. Columns (1),(2), (3), and (5), (6) and (7) show OLS estimates. Robust standard errors are shown in brackets. Standard errors are clustered on the team level (col. (1) and (5)) or the day level (col. (2), (6)), or on team and day (col. (3), (7)), respectively. Columns (4) and (8) show GLS estimates, accounting for team-specific AR(1) disturbances within teams and heteroscedasticity across teams. $* * *, * * *$ indicate significance at $1-, 5-$, and 10 -percent level, respectively.

Table 8: Results: Interactions between Treatment and Piece Rates Over Time

\begin{tabular}{|c|c|c|c|c|c|c|c|c|}
\hline & \multicolumn{8}{|c|}{ Pieces Harvested } \\
\hline & \multicolumn{4}{|c|}{ Treatment: August 1-31 } & \multicolumn{4}{|c|}{ Treatment: after August 1} \\
\hline & (1) & $(2)$ & $(3)$ & $(4)$ & $(5)$ & $(6)$ & $(7)$ & $(8)$ \\
\hline Treatment Effect Aug. 1-15 & 0.037 & 0.037 & 0.037 & 0.054 & 0.044 & 0.044 & 0.044 & 0.055 \\
\hline Treatment Effect Aug. 16-31 & $0.266^{* *}$ & $0.266^{* * *}$ & $0.266^{* * *}$ & $0.259^{* * *}$ & $0.305 * *$ & $0.305^{* * *}$ & $0.305 * * *$ & $0.302^{* * *}$ \\
\hline [s.e.] & [0.092] & {$[0.066]$} & [0.099] & {$[0.078]$} & [0.099] & [0.073] & {$[0.107]$} & {$[0.082]$} \\
\hline $\begin{array}{l}\text { Treatment Effect after Aug. } 31 \\
\text { [s.e.] }\end{array}$ & & & & & $\begin{array}{l}0.150^{* * *} \\
{[0.047]}\end{array}$ & $\begin{array}{l}0.150^{* * *} \\
{[0.053]}\end{array}$ & $\begin{array}{l}0.150 * * * \\
{[0.057]}\end{array}$ & $\begin{array}{c}0.154^{* * *} \\
{[0.055]}\end{array}$ \\
\hline Interaction: & $0.093 * *$ & 0.093 & $0.093 *$ & 0.094 & $0.132 * * *$ & $0.132 * *$ & $0.132^{* *}$ & $0.128^{* *}$ \\
\hline Treatment Aug. 1-15 . Piece Rate & {$[0.037]$} & {$[0.063]$} & {$[0.053]$} & {$[0.059]$} & {$[0.039]$} & {$[0.064]$} & {$[0.057]$} & {$[0.057]$} \\
\hline Interaction: & $0.215^{* * *}$ & $0.215^{* * *}$ & $0.215^{* * *}$ & $0.243^{* * *}$ & $0.207^{* * *}$ & $0.207 * * *$ & $0.207 * * *$ & $0.237^{* * *}$ \\
\hline Treatment Aug. 16-31 . Piece Rate & {$[0.046]$} & {$[0.044]$} & {$[0.053]$} & {$[0.050]$} & {$[0.055]$} & {$[0.051]$} & {$[0.065]$} & {$[0.047]$} \\
\hline Interaction: & & & & & $0.135 * *$ & $0.135 * * *$ & $0.135 * * *$ & $0.142^{* * *}$ \\
\hline Treatment after Aug. 31 . Piece Rate & & & & & [0.046] & {$[0.027]$} & [0.048] & {$[0.027]$} \\
\hline Piece Rate & $\begin{array}{c}-0.198^{* * *} \\
{[0.050]}\end{array}$ & $\begin{array}{c}-0.198^{* * *} * \\
{[0.050]}\end{array}$ & $\begin{array}{c}-0.198 * * * \\
{[0.060]}\end{array}$ & $\begin{array}{c}-0.194 * * * \\
{[0.014]}\end{array}$ & $\begin{array}{c}-0.208^{* * *} * \\
{[0.046]}\end{array}$ & $\begin{array}{c}-0.208^{* * *} * \\
{[0.048]}\end{array}$ & $\begin{array}{c}-0.208 * * * \\
{[0.055]}\end{array}$ & $\begin{array}{c}-0.203^{* * *} * \\
{[0.014]}\end{array}$ \\
\hline Mean Age & -0.006 & -0.006 & -0.006 & -0.001 & -0.023 & -0.023 & -0.023 & -0.023 \\
\hline $\begin{array}{l}\text { (All Team Members) } \\
\text { Mean Years of Experience }\end{array}$ & $\begin{array}{c}{[0.033]} \\
0.168 * * *\end{array}$ & $\begin{array}{c}{[0.024]} \\
0.168 * * *\end{array}$ & $\begin{array}{c}{[0.036]} \\
0.168 * * *\end{array}$ & {$[0.025]$} & {$[0.031]$} & {$[0.022]$} & {$[0.033]$} & {$[0.025]$} \\
\hline $\begin{array}{l}\text { Mean Years of Experience } \\
\text { (All Team Members) }\end{array}$ & $\begin{array}{c}0.168 \\
{[0.046]}\end{array}$ & $\begin{array}{c}0.168+027] \\
{[0.027}\end{array}$ & {$[0.049]$} & {$[0.026]$} & {$[0.047]$} & {$[0.027]$} & {$[0.051]$} & {$[0.025]$} \\
\hline Mean Days Worked in the Current & 0.042 & 0.042 & 0.042 & 0.016 & 0.044 & 0.044 & 0.044 & 0.026 \\
\hline Season (All Team Members) & {$[0.056]$} & {$[0.051]$} & {$[0.065]$} & {$[0.046]$} & {$[0.050]$} & {$[0.052]$} & {$[0.061]$} & {$[0.044]$} \\
\hline Team Size & $0.113^{* * *}$ & $0.113^{* * *}$ & $0.113^{* * *}$ & $0.117^{* * *}$ & $0.111^{*} * *$ & $0.111^{*} * *$ & $0.111 * * *$ & $0.113^{* * *}$ \\
\hline & {$[0.013]$} & {$[0.015]$} & {$[0.019]$} & {$[0.012]$} & {$[0.013]$} & {$[0.015]$} & {$[0.018]$} & {$[0.011]$} \\
\hline Total Work Hours per Shift & $0.893^{* * *}$ & $0.893^{* * *}$ & $0.893^{* * *}$ & $0.893 * * *$ & $0.873^{*} * *$ & $0.873 * * *$ & $0.873 * * *$ & $0.867 * * *$ \\
\hline & {$[0.026]$} & {$[0.020]$} & {$[0.032]$} & [0.013] & {$[0.036]$} & {$[0.021]$} & {$[0.041]$} & [0.013] \\
\hline First of Two Shifts & -0.037 & -0.037 & -0.037 & -0.049 & -0.022 & -0.022 & -0.022 & -0.038 \\
\hline & {$[0.035]$} & {$[0.049]$} & {$[0.050]$} & {$[0.036]$} & {$[0.036]$} & {$[0.045]$} & {$[0.047]$} & {$[0.035]$} \\
\hline Team Manager Dummies & yes & yes & yes & yes & yes & yes & yes & yes \\
\hline Day Dummies & yes & yes & yes & yes & yes & yes & yes & yes \\
\hline Observations & 1,199 & 1,199 & 1,199 & 1,199 & 1,199 & 1,199 & 1,199 & 1,199 \\
\hline R-squared & 0.893 & 0.893 & 0.893 & & 0.898 & 0.898 & 0.898 & \\
\hline
\end{tabular}

Note: Observations are on the team-shift level. The dependent variable is total pieces of lettuce harvested. All variables except binary treatment indicators are standardized on the estimation sample. Columns (1), (2), (3), and (5), (6) and (7) show OLS estimates. Robust standard errors are shown in brackets. Standard errors are clustered on the team level (col. (1) and (5)) or the day level (col. (2), (6)), or on team and day (col. (3), (7)), respectively. Columns (4) and (8) show GLS estimates, accounting for team-specific AR(1) disturbances within teams and heteroscedasticity across teams. ***, **,* indicate significance at 1-, 5-, and 10-percent level, respectively. 
Table 9: Results: Task Allocation Within Teams

\begin{tabular}{|c|c|c|c|c|c|c|c|c|}
\hline & \multicolumn{4}{|c|}{$\begin{array}{l}\text { Fraction of Team } \\
\text { Treatment: August } 1-31\end{array}$} & \multicolumn{4}{|c|}{ king as Cutters } \\
\hline & $(1)$ & $(2)$ & $(3)$ & $(4)$ & $(5)$ & $(6)$ & $(7)$ & $(8)$ \\
\hline $\begin{array}{l}\text { Treatment Effect on Treated } \\
\text { [s.e.] } \\
\text { (p-value) }\end{array}$ & $\begin{array}{l}0.009^{*} \\
{[0.005]} \\
(0.095)\end{array}$ & $\begin{array}{c}0.009^{* * *} \\
{[0.003]} \\
(0.004)\end{array}$ & $\begin{array}{l}0.009^{*} \\
{[0.005]} \\
(0.089)\end{array}$ & $\begin{array}{c}0.008^{* *} \\
{[0.004]} \\
(0.042)\end{array}$ & $\begin{array}{c}0.01 \\
{[0.006]} \\
(0.127)\end{array}$ & $\begin{array}{c}0.010^{* * *} \\
{[0.003]} \\
(0.001)\end{array}$ & $\begin{array}{c}0.01 \\
{[0.006]} \\
(0.124)\end{array}$ & $\begin{array}{c}0.006 \\
{[0.003]} \\
(0.103)\end{array}$ \\
\hline Piece Rate & $\begin{array}{l}-0.001 \\
{[0.001]}\end{array}$ & $\begin{array}{l}-0.001 \\
{[0.001]}\end{array}$ & $\begin{array}{l}-0.001 \\
{[0.001]}\end{array}$ & $\begin{array}{l}-0.001 \\
{[0.001]}\end{array}$ & $\begin{array}{l}-0.001 \\
{[0.001]}\end{array}$ & $\begin{array}{l}-0.001 \\
{[0.001]}\end{array}$ & $\begin{array}{l}-0.001 \\
{[0.001]}\end{array}$ & $\begin{array}{l}-0.001 \\
{[0.001]}\end{array}$ \\
\hline $\begin{array}{l}\text { Mean Age } \\
\text { (All Team Members) }\end{array}$ & 0.003 & $0.003^{* *}$ & 0.003 & $0.003^{*}$ & 0.003 & $0.003^{*}$ & 0.003 & $0.003^{*}$ \\
\hline $\begin{array}{l}\text { Mean Years of Experience } \\
\text { (All Team Members) }\end{array}$ & $\begin{array}{l}{[0.002]} \\
-0.003 \\
{[0.004]}\end{array}$ & $\begin{array}{l}{[0.001]} \\
-0.003 \\
{[0.002]}\end{array}$ & $\begin{array}{l}{[0.002]} \\
-0.003 \\
{[0.004]}\end{array}$ & $\begin{array}{l}{[0.002]} \\
-0.003 \\
{[0.002]}\end{array}$ & $\begin{array}{l}{[0.003]} \\
-0.003 \\
{[0.004]}\end{array}$ & $\begin{array}{l}{[0.001]} \\
-0.003 \\
{[0.002]}\end{array}$ & $\begin{array}{l}{[0.003]} \\
-0.003 \\
{[0.004]}\end{array}$ & $\begin{array}{l}{[0.002]} \\
-0.003 \\
{[0.002]}\end{array}$ \\
\hline $\begin{array}{l}\text { Mean Days Worked in the Current } \\
\text { Season (All Team Members) }\end{array}$ & $\begin{array}{l}-0.007 \\
{[0.006]}\end{array}$ & $\begin{array}{c}-0.007^{* *} \\
{[0.003]}\end{array}$ & $\begin{array}{l}-0.007 \\
{[0.006]}\end{array}$ & $-0.008 * * *$ & $\begin{array}{l}-0.005 \\
{[0.005]}\end{array}$ & $\begin{array}{c}-0.005^{*} \\
{[0.003]}\end{array}$ & $\begin{array}{l}-0.005 \\
{[0.006]}\end{array}$ & $\begin{array}{c}-0.007^{* *} \\
{[0.003]}\end{array}$ \\
\hline Team Size & $\begin{array}{l}0.011^{* * *} * \\
{[0.002]}\end{array}$ & $\begin{array}{l}0.011^{* * * *} \\
{[0.001]}\end{array}$ & $\begin{array}{c}0.011^{* * *} \\
{[0.003]}\end{array}$ & $\begin{array}{l}0.012^{* * * *} \\
{[0.001]}\end{array}$ & $\begin{array}{l}0.012^{* * *} * \\
{[0.002]}\end{array}$ & $\begin{array}{c}0.012 * * * \\
{[0.001]}\end{array}$ & $0.012 * * *$ & $\begin{array}{c}0.012 * * * \\
{[0.001]}\end{array}$ \\
\hline Total Work Hours per Shift & $\begin{array}{l}-0.001 \\
{[0.001]}\end{array}$ & $\begin{array}{l}-0.001 \\
{[0.001]}\end{array}$ & $\begin{array}{l}-0.001 \\
{[0.002]}\end{array}$ & $\begin{array}{l}-0.001 \\
{[0.001]}\end{array}$ & $\begin{array}{l}-0.001 \\
{[0.001]}\end{array}$ & $\begin{array}{l}-0.001 \\
{[0.001]}\end{array}$ & $\begin{array}{l}-0.001 \\
{[0.002]}\end{array}$ & $\begin{array}{l}-0.001 \\
{[0.001]}\end{array}$ \\
\hline First of Two Shifts & $\begin{array}{l}-0.001 \\
{[0.002]}\end{array}$ & $\begin{array}{l}-0.001 \\
{[0.003]}\end{array}$ & $\begin{array}{l}-0.001 \\
{[0.003]}\end{array}$ & $\begin{array}{c}-0.004^{* *} \\
{[0.002]}\end{array}$ & $\begin{array}{l}-0.001 \\
{[0.003]}\end{array}$ & $\begin{array}{l}-0.001 \\
{[0.003]}\end{array}$ & $\begin{array}{l}-0.001 \\
{[0.003]}\end{array}$ & $\begin{array}{c}-0.004^{* *} \\
{[0.002]}\end{array}$ \\
\hline $\begin{array}{l}\text { Team Manager Dummies } \\
\text { Day Dummies }\end{array}$ & $\begin{array}{l}\text { yes } \\
\text { yes }\end{array}$ & $\begin{array}{l}\text { yes } \\
\text { yes }\end{array}$ & $\begin{array}{l}\text { yes } \\
\text { yes }\end{array}$ & $\begin{array}{l}\text { yes } \\
\text { yes }\end{array}$ & $\begin{array}{l}\text { yes } \\
\text { yes }\end{array}$ & $\begin{array}{l}\text { yes } \\
\text { yes }\end{array}$ & $\begin{array}{l}\text { yes } \\
\text { yes }\end{array}$ & $\begin{array}{l}\text { yes } \\
\text { yes }\end{array}$ \\
\hline $\begin{array}{l}\text { Observations } \\
\text { R-squared }\end{array}$ & $\begin{array}{c}1,199 \\
0.48\end{array}$ & $\begin{array}{c}1,199 \\
0.48\end{array}$ & $\begin{array}{c}1,199 \\
0.48\end{array}$ & 1,199 & $\begin{array}{l}1,199 \\
0.482\end{array}$ & $\begin{array}{l}1,199 \\
0.482\end{array}$ & $\begin{array}{l}1,199 \\
0.482\end{array}$ & 1,199 \\
\hline
\end{tabular}

Note: Observations are on the team-shift level. The dependent variable is the fraction of the team working as cutters. All variables except binary treatment indicators are standardized on the estimation sample. Columns (1),(2), (3), and (5), (6) and (7) show OLS estimates. Robust standard errors are shown in square brackets. Standard errors are clustered on the team level (col. (1) and (5)) or the day level (col. (2), (6)), or on team and day (col. (3), (7)), respectively. Columns (4) and (8) show GLS estimates, accounting for team-specific AR(1) disturbances within teams and heteroscedasticity across teams. ${ }^{* *}, * *, *$ indicate significance at $1-, 5-$, and 10 -percent level, respectively. 